\title{
Development of a Portfolio Diet Score and Its Concurrent and Predictive Validity Assessed by a Food Frequency Questionnaire
}

\author{
Andrea J. Glenn ${ }^{1,2,3,+}$, Beatrice A. Boucher ${ }^{1,+}$ D , Chloe C. Kavcic ${ }^{4}$, Tauseef A. Khan ${ }^{1,2,3}$, Melanie Paquette ${ }^{1,2}$, \\ Cyril W. C. Kendall 1,2,3,5, Anthony J. Hanley 1,6,7,8, David J. A. Jenkins 1,2,3,8,9,10 \\ and John L. Sievenpiper $1,2,3,8,9,10, *$
}

\section{check for} updates

Citation: Glenn, A.J.; Boucher, B.A.; Kavcic, C.C.; Khan, T.A.; Paquette, M.; Kendall, C.W.C.; Hanley, A.J.; Jenkins, D.J.A.; Sievenpiper, J.L. Development of a Portfolio Diet Score and Its Concurrent and Predictive Validity Assessed by a Food Frequency Questionnaire. Nutrients 2021, 13, 2850. https://doi.org/10.3390/ nu13082850

Academic Editor: Megan A. McCrory

Received: 17 June 2021

Accepted: 17 August 2021

Published: 19 August 2021

Publisher's Note: MDPI stays neutral with regard to jurisdictional claims in published maps and institutional affiliations.

Copyright: (C) 2021 by the authors Licensee MDPI, Basel, Switzerland. This article is an open access article distributed under the terms and conditions of the Creative Commons Attribution (CC BY) license (https:/ / creativecommons.org/licenses/by/ $4.0 /)$.
1 Department of Nutritional Sciences, Temerty Faculty of Medicine, University of Toronto, Toronto, ON M5S 1A8, Canada; andrea.glenn@utoronto.ca (A.J.G.); beatrice.boucher@utoronto.ca (B.A.B.); tauseef.khan@utoronto.ca (T.A.K.); melanie.paquette@utoronto.ca (M.P.); cyril.kendall@utoronto.ca (C.W.C.K.); anthony.hanley@utoronto.ca (A.J.H.); david.jenkins@utoronto.ca (D.J.A.J.)

2 Clinical Nutrition and Risk Factor Modification Center, St. Michael's Hospital, Toronto, ON M5C 2T2, Canada

3 Toronto 3D Knowledge Synthesis and Clinical Trials Unit, St. Michael's Hospital, Toronto, ON M5C 2T2, Canada

4 School of Nutrition, Ryerson University, Toronto, ON M5B 2K3, Canada; chloe.kavcic@ryerson.ca

5 College of Pharmacy and Nutrition, University of Saskatchewan, Saskatoon, SK S7N 5E5, Canada

6 Department of Medicine, Dalla Lana School of Public Health, University of Toronto, Toronto, ON M5T 3M7, Canada

7 Leadership Sinai Centre for Diabetes, Mount Sinai Hospital, Toronto, ON M5G 1X5, Canada

8 Department of Medicine, Temerty Faculty of Medicine, University of Toronto, Toronto, ON M5S 1A8, Canada

9 Li Ka Shing Knowledge Institute, St. Michael's Hospital, Toronto, ON M5B 1A6, Canada

10 Division of Endocrinology and Metabolism, Department of Medicine, St. Michael's Hospital, Toronto, ON M5C 2T2, Canada

* Correspondence: john.sievenpiper@utoronto.ca; Tel.: +1-416-867-3732

$+\quad$ These authors contribute equally to this work.

Abstract: The Portfolio Diet, a plant-based portfolio of cholesterol-lowering foods, has been shown to reduce low-density lipoprotein cholesterol (LDL-C), and other cardiovascular risk factors, in randomized controlled trials (RCTs). It is not known if these beneficial effects translate to a lower incidence of cardiovascular disease (CVD). To support examinations between Portfolio Diet adherence and disease, a Portfolio Diet score (PDS) was developed and its predictive and concurrent validity was assessed within the Toronto Healthy Diet Study, a six-month RCT in overweight adults. Predictive validity was assessed using change in the PDS measured by food frequency questionnaire (FFQ) and concomitant change in LDL-C from baseline to six months using multiple linear regression, adjusted for potential confounders $(n=652)$. Concurrent validity was assessed in a subset of participants ( $n=50)$ who completed the FFQ and a 7-day diet record (7DDR) at baseline. The PDS determined from each diet assessment method was used to derive correlation coefficients and Bland-Altman plots to assess the between-method agreement. The change in PDS was inversely associated with change in LDL-C ( $\beta$ coefficients: $-0.01 \mathrm{mmol} / \mathrm{L}$ (95\% confidence intervals (CIs): $-0.02,-0.002 ; p$ = 0.02). The correlation between the PDS from the FFQ and 7DDR was 0.69 (95\% CIs: 0.48, 0.85). The Bland-Altman plot showed reasonable agreement between the score from the FFQ and 7DDR. These findings indicate predictive validity of the PDS with lower LDL-C, and reasonable concurrent validity of the PDS as assessed by an FFQ against a 7DDR.

Keywords: portfolio diet; validity; diet index; dietary pattern

\section{Introduction}

The Portfolio Diet, or Dietary Portfolio, is a plant-based dietary pattern that was developed in the early 2000s as a "portfolio" of four cholesterol-lowering foods and nutrients 
(plant protein, viscous fiber, nuts and phytosterols) [1] that each have Health Canada, U.S Food and Drug Administration, and/or European Food Safety Authority approved health claims for cholesterol-lowering or cardiovascular disease (CVD) risk reduction [2-9]. The Portfolio Diet is low in saturated fat and cholesterol (National Cholesterol Education Program (NCEP) Step II diet) [10], with four food components added to the diet (based on a $2000 \mathrm{kcal}$ diet): $50 \mathrm{~g}$ plant protein from soy products or dietary pulses such as beans, peas, chickpeas, and lentils; $20 \mathrm{~g}$ viscous soluble fiber from oats, barley, psyllium, eggplant, okra, and certain fruit; $45 \mathrm{~g}$ nuts (tree nuts or peanuts); and $2 \mathrm{~g}$ phytosterols originally provided as an enriched margarine [1,11-14]. A fifth component was later added to the diet, which includes plant-based monounsaturated fats (MUFAs) in the form of olive, canola, high oleic sunflower oils, or avocados ( $45 \mathrm{~g} /$ day) to further improve blood lipids, including high-density lipoprotein (HDL) cholesterol [15]. Early findings from a metabolically controlled randomized controlled trial (RCT) showed that the low density-lipoprotein cholesterol (LDL-C) lowering effect of the Portfolio Diet was similar to $20 \mathrm{mg}$ lovastatin ( $-28.6 \%$ vs. $-30.9 \%$ ) [12]. A recent systematic review and meta-analysis of metabolically controlled and ad libitum trials showed that the Portfolio Diet significantly lowered LDL-C by $17 \%$ (27\% in the intended combination with an NCEP Step II diet), among several other CVD risk factors, including non-HDL-C, apolipoprotein B and C-reactive protein [16].

It is currently not known if the LDL-C lowering effect of the Portfolio Diet translates into lower risk of clinical CVD events. Conducting a long-term RCT with CVD as the primary outcome would be preferable; however, this type of trial will be challenging to conduct from a logistical and funding perspective. Therefore, analyses of observational studies, such as prospective cohort studies, may help assess the long-term effectiveness of the Portfolio Diet.

A priori dietary patterns that are based upon nutrition knowledge of a diet shown to be healthful, such as the Portfolio Diet, are typically assessed with disease outcomes in prospective cohorts through the creation of a diet index or score. However, adherence to the Portfolio Diet has not been assessed in these study designs, aside from two recent studies by our group [17,18], and a diet index/scoring system for this diet has not been formally described or evaluated in terms of its validity. A Portfolio Diet score (PDS) will be particularly useful applied to food frequency questionnaires (FFQs), as they are the most common diet assessment tools used in population-based observational studies [19], including prospective cohort studies. The objectives of this study were to describe the development of a PDS and to assess the predictive and concurrent validity of our PDS as measured by an FFQ. Predictive validity was assessed against LDL-C and concurrent validity was assessed between the PDS from the FFQ and 7-day diet records as the reference method.

\section{Methods}

\subsection{Study Population}

The development and validation of the PDS was conducted within the Toronto Healthy Diet Study (THDS). The THDS was a six-month population-based RCT assessing the effects of a healthy diet intervention in overweight (BMI $>25 \mathrm{~kg} / \mathrm{m}^{2}$ ) adults in Toronto, with 960 participants completing a baseline assessment (including FFQ, blood sample and other questionnaires). Participants were recruited between 2005 and 2009 using public advertisements (e.g., on transit). Participants were randomized as households (households of one or more), and all members of the same household received the same diet $(n=94$ two-member households; $n=3$ three-member households). Women who reported a total daily energy intake of $<500$ or $>4000 \mathrm{kcal}$, and men with a $<800$ or $>5000 \mathrm{kcal}$ on the baseline FFQ were excluded from the analysis. Participants with missing LDL-C or FFQ assessment at six months were also excluded from the predictive validation analysis. A total of 652 participants were included in the predictive validity analysis and 50 in the concurrent validity analysis (Figure 1). Thirty-two participants were included (i.e., had overlap) in both the predictive and concurrent validity analyses (Figure 1). 


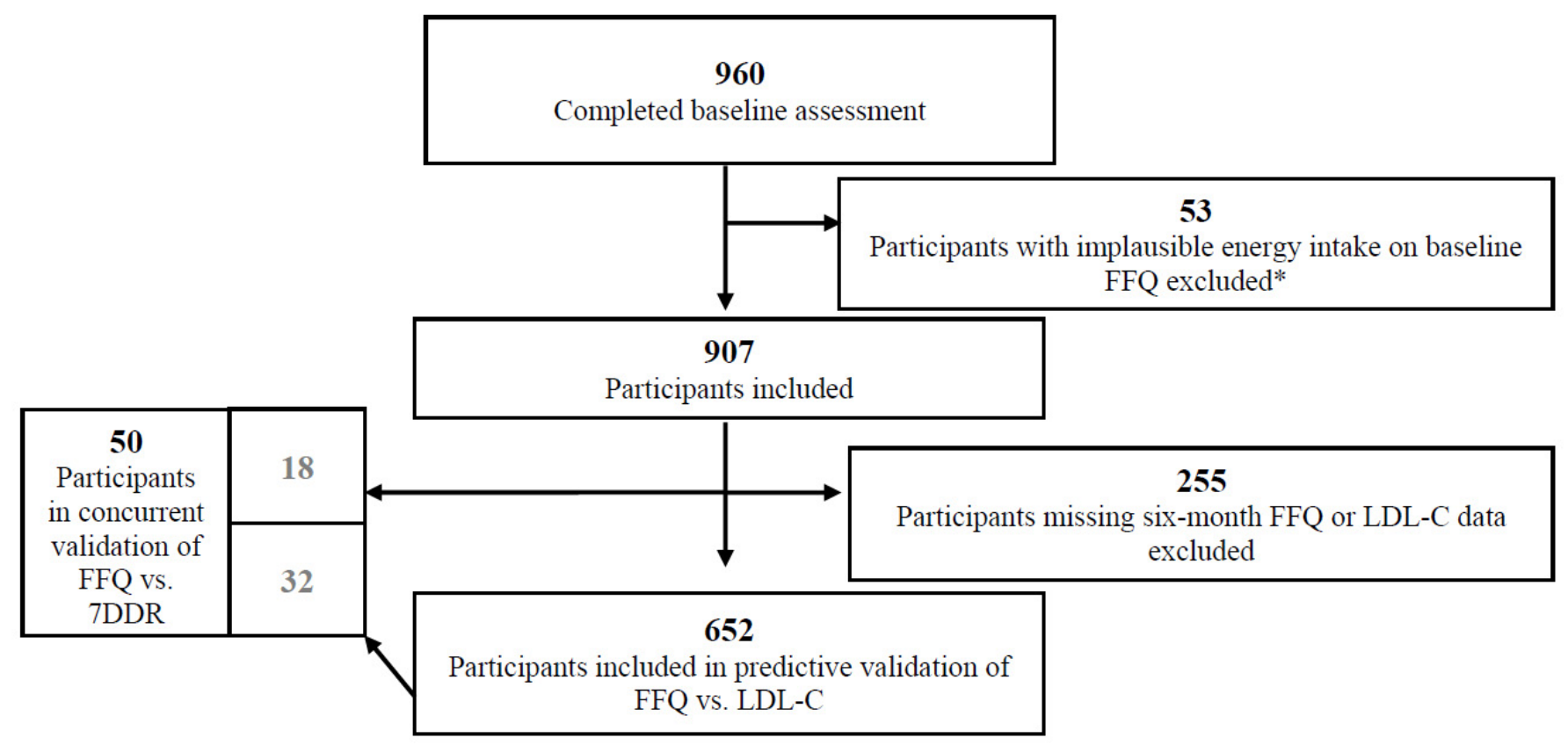

Figure 1. Flowchart for the validation study sample, Toronto Healthy Diet Study. Abbreviations: FFQ, food frequency questionnaire; LDL-C, low-density lipoprotein cholesterol; 7DDR, 7-day diet record. * Women who reported a total daily energy intake of $<500$ or $>4000 \mathrm{kcal}$, and men with a $<800$ or $>5000 \mathrm{kcal}$ on the baseline FFQ were excluded from the analysis.

\subsection{Study Design}

Participants completed an FFQ, other questionnaires, and provided fasting blood, anthropometric, and blood pressure measurements at baseline and six months. All visits took place at St. Michael's Hospital in Toronto. Research ethics boards of the University of Toronto and St. Michael's Hospital approved the protocol and all participants provided written informed consent. The trial was registered with ClinicalTrials.gov (NCT00516620). Further information on the trial has been previously published [20].

\subsection{Nutrition Intervention}

The trial was a six-month intervention comparing the control group (general advice to follow Canada's Food Guide, either the 1992 or 2007 edition depending on recruitment date [21]) to those randomized to receive one of three diet interventions: (1) dietary advice from a Registered Dietitian (RD) to follow healthy eating principles (such as increased fruit and vegetable intake, whole grain intake, etc.), (2) weekly food baskets reflecting the dietary advice, or (3) dietary advice from an RD and weekly food baskets.

\subsection{Dietary Assessment}

\subsubsection{Food Frequency Questionnaire}

A semi-quantitative FFQ asking about usual consumption over the past month was self-administered by study participants at baseline and six months [20]. Serving sizes were preassigned and most food items had 8 or 9 continuous frequency responses ranging from 'never' to ' 2 or more' or ' 4 or more' per day. The original validated FFQ by Willet et al. $[22,23]$ was expanded to 184 food items to improve the assessment of viscous fiber, nuts, whole grains, glycemic index, and caffeine. Modifications included adding 26 food items, including six items relevant to the Portfolio Diet (cooked oat bran, barley, eggplant, almond butter, almonds, and walnuts), and changes to expand or clarify inclusions (e.g., raspberries and blackberries were added to the item for strawberries). Coding rules for open-ended questions about the usual type and brand of cold breakfast cereals (e.g., Bran Buds), cooking oils, margarine, and multivitamin supplements were also revised for the Canadian market. Supplement items included dose and duration of use for 
multivitamins and 10 individual nutrients, as well as a checklist of 10 other supplements (including Metamucil) to identify those taken currently at least once a week. The FFQs were mailed to participants and reviewed for completion by study RDs at clinic visits or via telephone. FFQ analysis to derive food and nutrient intakes was based on USDA values and provided by the Nutrition Department at Harvard T.H. Chan School of Public Health.

\subsubsection{Diet Records}

A subsample of 50 participants also completed a 7-day diet record (7DDR) on consecutive days at baseline. A 7DDR booklet and instructions were mailed to participants after completing the FFQ. These participants were some of the first to be recruited into the study, and they completed both FFQs and 7DDR before the latter were discontinued due to high respondent burden. Study RDs reviewed the 7DDRs for completeness with participants at the clinic or over the telephone. The 7DDRs were entered into and analyzed using ESHA Research Food Processor SQL: Nutrition Analysis and Fitness Program (Copyright 2012, ESHA Research).

\subsection{Development of the Portfolio Diet Score}

Development of the PDS followed a similar approach to the well-known Dietary Approaches to Stop Hypertension (DASH) diet score [24], which originated from RCT evidence and then later applied to other study designs. We considered several factors during the development of our PDS, including:

\subsubsection{Using Dietary Recommendations from the RCTs or Population-Specific Cut-Offs}

In the Portfolio Diet RCTs, participants were provided with foods and/or advised to consume specific foods to meet the following recommendations: $50 \mathrm{~g}$ of plant protein, $20 \mathrm{~g}$ of viscous fiber, $45 \mathrm{~g}$ of nuts, $2 \mathrm{~g}$ of phytosterols, $45 \mathrm{~g}$ of MUFAs and $\leq 7 \%$ total energy from saturated fat and $\leq 200 \mathrm{mg}$ dietary cholesterol [16]. Using these specific recommendations as adherence cut points appeared ideal at first; however, it is important to consider the context in which we are applying the created score. In the current study, the PDS is being applied to data from a healthy diet intervention trial, with plans to apply the PDS to other population level studies, such as large prospective cohorts, in the future. As these study populations were not advised to follow the Portfolio Diet, it is likely that intake of certain recommended foods or nutrients will remain below the desired cut-off level (e.g., $50 \mathrm{~g}$ of plant protein) for many participants and therefore, these cut-off levels will have reduced discriminating power between groups. The ability to discriminate between groups of individuals is necessary to assess disease outcome associations [25,26]. It is also important to consider that even if a population does not meet the Portfolio Diet specific recommendations, beneficial changes may still occur, as reported in the Jenkins et al., 2011 dietary advice RCT where significant clinically relevant reductions (-15\%) in LDL-C were seen, although participants were only $43 \%$ adherent on average [14]. Given these considerations, we used population-specific cut-offs rather than the RCT recommendations to create the PDS. To compare Portfolio Diet adherence in the current study against RCT recommendations, we estimated mean intake of PDS components by quintiles using FFQ data at baseline and six months $(n=652)$.

\subsubsection{Using a Nutrient or Food-Based Score}

The Portfolio Diet recommendations listed above were initially conceptualized as nutrients (g/day); however, this is not how the dietary advice is provided. Individuals, including the participants in the Portfolio Diet RCTs [16], receive education to include or limit specific foods. Food-based scores (assessed as servings per day, for example), rather than nutrient-based scores, are also generally easier to interpret and to apply to multiple diet assessment settings and tools (FFQs, diet records, etc.) Food-based scores do not require compositional databases to include the specific nutrients of interest or to be updated for changes in the food supply or changes in analytical methods. Food-based approaches are 
also more in line with current dietary and clinical practice guidelines that focus on foods and dietary patterns, rather than on macro and micronutrient recommendations [27-30].

The one exception to a food-based approach was for phytosterols, where we estimated intake in mg/day. In the Portfolio Diet RCTs, phytosterols were provided through supplemented foods (originally as an enriched margarine). As these products were not available to participants in the current study and may not be applicable to other population-based studies, we assessed total dietary intake of phytosterols, which are present in all plant foods. In anticipation of some overlap of phytosterol food sources with the other plant-based components recommended in the diet (plant protein, viscous fiber, nuts and MUFAs), we assessed interitem correlations between each of the score components $(n=652)$.

\subsubsection{Choice of Quantiles}

The choice of quantiles to use when constructing population-specific cut-offs in diet scores is subjective and various quantiles have been used in the literature. The most common approaches have used medians (assigning 0 points for below and 1 point for above), such as in several Mediterranean or Nordic diet scores [31-33], as well as quintiles (assigning 1 and 5 points across quintiles), such as in a DASH or the overall, healthy and unhealthy plant-based diet indices [24,34]. Our a priori plan was to use the quintile-based approach; however, we conducted a sensitivity analysis to compare the association of the PDS with LDL-C using the median approach (score range 0-6) and the quintile approach (score range 6-30) using the same methods described below for the predictive validity analysis $(n=652)$ to assess how the two cut-off approaches may impact the results. Medians or quintiles of intake in our study were assessed separately for men and women.

\subsubsection{Weight of Each Diet Component}

A limitation of diet scores reported in the literature is that the weight of each score component is not taken into account [25,35-37]. This lack of reporting in previous studies may be because the relative effect of different components on the outcome of interest is unknown, and the weight is likely different for various health outcomes [25,35-37]. The researchers who created the DASH diet index reported that it is difficult to specify the contribution of each food group contained in their score to CVD risk [24]. However, to create the PDS, we explored weighting the score components differently based on past LDL-C research. Previous evidence showed that plant protein, viscous fiber, nuts and phytosterols can lower LDL-C by $\sim 5 \%$ each [38-43], whereas the low saturated fat and cholesterol component lowered LDL-C by $\sim 10 \%$ in the Portfolio Diet trials [16]. Consequently, we conducted a sensitivity analysis where we provided double weight (i.e., points) to the low saturated fat/cholesterol component to explore if there were differences in the PDS association with LDL-C, using the same methods described below for the predictive validity analysis $(n=652)$.

\subsection{Calculating the PDS}

Food items relevant to the Portfolio Diet were identified in the FFQ and categorized into the six Portfolio Diet components: plant protein, viscous fiber, nuts, phytosterols, monounsaturated fats (MUFAs), and saturated fat/cholesterol sources. Since food items had pre-assigned serving sizes, the frequency category reported for each food item was directly converted to servings/day (i.e., "2-4 times per week" was 0.43 servings/day). For all components, servings/day were summed over all consumed food items in each component. Phytosterols required an additional step to convert servings/day to $\mathrm{mg} /$ day using serving size weights provided by the Nutrition Department at the Harvard T.H. Chan School of Public Health, and food content values $(\mathrm{mg} / 100 \mathrm{mg}$ ) in our phytosterol database described below.

More points were given to participants with higher intakes of foods recommended in the Portfolio Diet, whereas less points were given to participants with higher intakes of foods to be limited in the Portfolio Diet. These points were given for each of the six 
components by splitting them into sex-specific quintiles: those in the highest quintile of foods recommended (such as nuts) received five points and those in the lowest quintile received one point. Reverse scoring was used for those foods to be limited (such as foods high in saturated fat), where those with the highest intake (quintile 5) received one point, and those with the lowest intake (quintile 1) received five points. The total points were then added for each participant, resulting in a possible score range between 6 and 30, with higher scores indicating higher adherence to the Portfolio Diet. A similar approach was utilized when creating the score using medians, where those above the median for foods recommended in the diet received 1 point, and those below received 0 points (score range $0-6$ ).

We then used the 7DDR data to create the PDS. To obtain comparable data from the FFQ and 7DDR, the unique foods from the 7DDRs were matched to the six components of our PDS. Serving sizes from the 7DDR were converted to match those included on the FFQ. The food group components created from the 7DDRs were then scored in the same way as discussed above to create the PDS in the FFQ.

\subsection{Phytosterol Database}

Phytosterols were the only score component based on mg/day. The FFQ compositional database from the Harvard T.H. Chan School of Public Health used in this study and the 7DDR compositional database (ESHA Research Food Processor SQL: Nutrition Analysis and Fitness Program (Copyright 2012, ESHA Research)) did not have phytosterols available as a nutrient variable. Therefore, we developed a phytosterol database (mg/100 g) based on literature values and existing databases and created recipes to match the food items in the FFQ and 7DDRs. Several data sources were used, including the Finnish Food Composition Database [44], the European Prospective Cohort into Cancer (EPIC) Netherlands database [45], the United States Department of Agriculture (USDA) [46], and other literature [47-51]. Original analytical values were used when available, as well as imputed values for unavailable foods where similar foods were available, and calculated values for recipes using foods with available and imputed values. Recipes were analyzed using the ESHA program. Since the content data of individual phytosterols were not consistently available for all foods, we assessed total phytosterols summing values for the 5-7 most frequently occurring phytosterols in foods reported in the literature (sitosterol, campesterol, stigmasterol, 5-avenasterol, brassicasterol, sitostanol and campestanol).

\subsection{LDL-C Assessment}

Blood samples were collected after a 12-h overnight fast at baseline and six-month clinic visits and analyzed at the St. Michael's Hospital Core Laboratory, Toronto. LDL-C was calculated in $\mathrm{mmol} / \mathrm{L}$ by the method of Friedewald et al. [52]

\subsection{Covariate Assessment}

Measurements of demographic, socioeconomic, medical and lifestyle variables, including smoking and medical history, were obtained through structured self-administered questionnaires and reviewed by the study RDs. Physical activity was assessed using the short-form International Physical Activity Questionnaire (IPAQ) [53]. Participants' body weight and height were measured without shoes and in light indoor clothing at baseline.

\subsection{Statistical Analysis}

Descriptive analysis to compare the baseline characteristics (including intake assessed by baseline FFQ) of those in the predictive validation group using FFQ and LDL-C data to the concurrent validation subset that completed the FFQ and 7DDR was conducted by using Student $t$-test for continuous variables and chi-square test for categorical variables.

For the predictive validity analysis, we used multiple linear regression and Pearson correlation coefficients to examine the association and correlation of change in the PDS with concomitant change in LDL-C, and logistic regression to examine the odds of having 
a $5 \%$ reduction in LDL-C with change in the PDS. In all models, we used robust variance estimates to account for intra-cluster correlations $(n=94$ two-member households; $n=3$ three-member households) to account for households randomized together in the main trial. We adjusted for the following covariates in the fully adjusted model: sex (male/female), age (continuous), baseline LDL-C (continuous), energy intake (continuous), use of cholesterol-lowering medications (yes/no), ethnicity (Caucasian/Asian/African and Caribbean/Other/Unknown), BMI (continuous), smoking status (current/never and past), family history of CVD (yes/no), education (high school or less/undergraduate and college/graduate), physical activity level (low/medium/high) and intervention group (control/intervention). These same methods were repeated in our sensitivity analyses to assess the effect of median and quintile cut-offs, and weighting of the saturated fat/cholesterol component during the PDS development.

For the concurrent validation analyses, we calculated Pearson correlation coefficients between the PDS from the FFQ and the PDS from the 7DDR, with and without energy adjustment (using the residual method) as absolute score (6-30) and as quantiles (1-4). We further calculated deattenuated correlation coefficients between the PDS computed from the FFQs and 7DDR, correcting for within-person error in the 7DDR, using the following formula:

$$
P c=P o \sqrt{\left(1+\frac{\gamma}{k}\right)}
$$

where $P_{c}$ is the corrected correlation coefficient between the FFQ and 7DDR, $P o$ is the observed energy-adjusted correlation coefficient between the FFQ and 7DDR, $\gamma$ is the ratio of within-to-between-person variation in the 7DDR PDS, and $k$ is the number of diet record days recorded ( $k=7$ in this instance).

We also calculated deattenuated Pearson or Spearman correlation coefficients between the single components (as quantiles and absolute amounts) of the PDS from the FFQ and from the 7DDR, as well as energy (kcal) and macronutrients (carbohydrate, protein, fat). The single components (absolute amounts) of the PDS were log transformed after adding ( 0.0001 servings/day) to the data to allow the zeros to be fixed to a non-zero value as the components were positively skewed. We additionally analysed the absolute agreement between the two methods (FFQ and 7DDR) with the Bland-Altman method, which determines the average agreement between two methods by calculating the mean of their differences (FFQ-7DDR) against the mean intake of the two measures (FFQ + $7 D D R / 2$ ). The $95 \%$ limits of agreement (LOA) provide an interval within which $95 \%$ of these differences are expected to fall.

Lastly, we calculated the proportion of participants correctly categorized (same quantile) and grossly misclassified (opposite quantile) for the PDS and single components. Statistical tests were 2 -sided and $p<0.05$ was considered statistically significant. The statistical analyses were conducted with Stata statistical software (Stata Statistical Software: Release 15. College Station, TX, USA).

\section{Results}

\subsection{Development of the PDS}

Table 1 reports the specific FFQ food items and their respective serving sizes that contributed to the PDS. Mean intake among the highest quintiles for each PDS component failed to meet the recommendations from the Portfolio Diet RCTs, as expected, with the exception of low dietary cholesterol intake ( $<200 \mathrm{mg} /$ day) (Table S1). 
Table 1. Portfolio Diet components and food items included in the FFQ.

\begin{tabular}{|c|c|}
\hline Portfolio Diet Components & Food Items (Serving Sizes) in FFQ ${ }^{a}$ \\
\hline $\begin{array}{l}\text { Plant protein, } \\
\text { servings/day }\end{array}$ & $\begin{array}{l}\text { Tofu, soybeans, or vegetable protein ( } 3-4 \mathrm{oz}) \text {; peas or lima beans }(1 / 2 \text { cup); lentils or beans, kidney, } \\
\text { pinto, black-eyed, chickpeas, etc. ( } 1 / 2 \text { cup }) \text {; soymilk ( } 8 \text { oz glass })\end{array}$ \\
\hline $\begin{array}{l}\text { Viscous fiber, } \\
\text { servings/day }\end{array}$ & $\begin{array}{l}\text { Cold breakfast cereal, Bran buds ( } 1 \text { cup); cooked oatmeal ( } 1 \text { cup); cooked oat bran ( } 1 \text { cup); oat bran } \\
\text { added to food ( } 1 \text { tbsp); barley ( } 1 \text { cup); fresh apples or pears }(1) \text {; applesauce }(1 / 2 \text { cup); oranges, } \\
\text { tangerines, clementines }(1) \text {; grapefruit }(1 / 2) \text {; strawberries, raspberries or blackberries }(1 / 2 \text { cup); } \\
\text { blueberries }(1 / 2 \text { cup); okra }(1 / 2 \text { cup); eggplant }(1 / 2 \text { cup); Metamucil supplement }(2 \text { tsp) }\end{array}$ \\
\hline $\begin{array}{l}\text { Nuts, } \\
\text { servings/day }\end{array}$ & $\begin{array}{l}\text { Peanut butter (1 tbsp); almond butter (1 tbsp); peanuts ( } 1 \mathrm{oz}) \text {; almonds }(1 \mathrm{oz}) \text {; walnuts }(1 \mathrm{oz}) \text {; } \\
\text { other nuts ( } 1 \mathrm{oz})\end{array}$ \\
\hline $\begin{array}{l}\text { Phytosterols, } \\
\text { mg/day }\end{array}$ & Estimated from all plant foods \\
\hline $\begin{array}{l}\text { MUFAs }{ }^{c} \text {, } \\
\text { servings/day }\end{array}$ & Avocado (1/2); olive oil, added to food or bread ( 1 tbsp); olive oil salad dressing ( 2 tbsp) \\
\hline $\begin{array}{l}\text { Saturated fat/cholesterol, } \\
\text { servings/day }\end{array}$ & 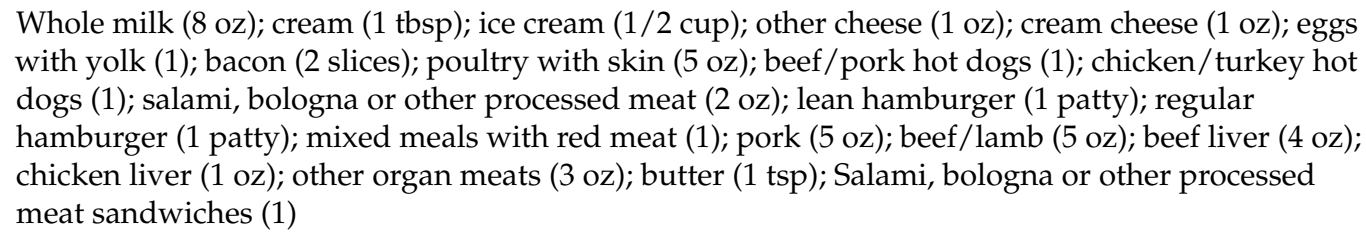 \\
\hline
\end{tabular}

Semi-colons between food items indicate separate line items on the FFQ. Abbreviations: FFQ, food frequency questionnaire; MUFAs, monounsaturated fatty acids. ${ }^{a}$ Six items relevant to the Portfolio Diet were added to the FFQ (cooked oat bran, barley, eggplant, almond butter, almonds, and walnuts); FFQ changes were made to expand or clarify inclusions (e.g., raspberries and blackberries were added to the item for strawberries). Coding rules for open-ended questions about the usual type and brand of cold breakfast cereals (e.g., Bran Buds), cooking oils, margarine, and multivitamin supplements were revised for the Canadian market. ${ }^{\text {b }}$ Serving size of 2 tsp was assigned based on recommendations in Metamucil instructions. Intake frequency of once per week was assigned as FFQ asked about supplements taken "at least once per week". ${ }^{c}$ Total olive oil not captured, as frying/sautéing and baking questions did not quantify olive oil consumption.

Interitem correlations between the six individual score components were highest between phytosterols and plant protein, viscous fiber, nuts and MUFAs, with correlations ranging between 0.30 and 0.41 ; however, these correlations still suggested a sufficiently unique variance with the other components [54] (Table S2). In our sensitivity analysis assessing median vs. quintile cut-offs, the quintile approach resulted in more favorable results with LDL-C than when the median was used, which did not show significant inverse associations with LDL-C (data not shown), as expected. Finally, in the sensitivity analyses providing double weight to the low saturated fat/cholesterol component, no change was observed in the association with LDL-C (data not shown); thus, the PDS with equal weights for each component was used in the final analyses.

\subsection{Validation of PDS by FFQ}

Assessment of the PDS and its validity was based on quintiles of intake and with equal weight given to each component, as described above. The participants included in the concurrent validation subsample $(n=50)$ were different from those in the larger predictive validation group $(n=652)$ in that more were male and had a lower baseline BMI (Table 2). Mean intake by baseline FFQ was significantly higher for phytosterols in the predictive validation group, although no other differences were observed in overall PDS or the other five components. 
Table 2. Baseline characteristics of the participants included in the predictive and concurrent validation analyses.

\begin{tabular}{|c|c|c|c|}
\hline Characteristic, Mean (SD) $/ n(\%)$ & $\begin{array}{l}\text { Predictive Validation } \\
\qquad(n=652)\end{array}$ & $\begin{array}{l}\text { Concurrent Validation } \\
\qquad(n=50)\end{array}$ & $p$-Value \\
\hline Age, year & $45.2(12.6)$ & $45.3(11.5)$ & 0.96 \\
\hline Sex, female & $493(76)$ & $31(62)$ & 0.03 \\
\hline Current smoker & $45(7)$ & $3(7)$ & 0.07 \\
\hline \multicolumn{4}{|l|}{ Exercise level } \\
\hline Low & $104(16)$ & $7(14)$ & \multirow{3}{*}{0.62} \\
\hline Medium & $462(71)$ & $34(68)$ & \\
\hline High & $86(13)$ & $9(18)$ & \\
\hline Cholesterol-lowering medication use & $43(7)$ & $2(4)$ & 0.47 \\
\hline Blood pressure lowering medication use & $64(10)$ & $6(12)$ & 0.62 \\
\hline BMI & $32.1(5.42)$ & $28.9(4.57)$ & $<0.001$ \\
\hline Family history of CVD & $288(44)$ & $20(40)$ & 0.58 \\
\hline Total energy intake, kcal/d & 1995 (707) & $2056(822)$ & 0.56 \\
\hline Baseline LDL-C, mmol/L & $3.24(0.80)$ & $3.25(0.70)$ & 0.93 \\
\hline \multicolumn{3}{|l|}{ Highest education completed } & \multirow{4}{*}{0.54} \\
\hline High school or less & $212(33)$ & $14(28)$ & \\
\hline Undergraduate/college degree & $294(45)$ & $25(50)$ & \\
\hline Graduate degree & $144(22)$ & $11(22)$ & \\
\hline \multicolumn{3}{|l|}{ Ethnicity $^{\mathrm{a}}$} & \multirow{6}{*}{$<0.001$} \\
\hline Caucasian & $416(64)$ & $25(50)$ & \\
\hline Asian & $70(11)$ & $3(6)$ & \\
\hline African \& Caribbean & $49(8)$ & $0(0)$ & \\
\hline Other & $58(9)$ & $1(2)$ & \\
\hline Unknown & $59(9)$ & $21(42)$ & \\
\hline Control group & $270(41)$ & $27(54)$ & 0.08 \\
\hline $\begin{array}{l}\operatorname{PDS}^{\mathrm{b}} \\
\text { mean }(\mathrm{SD}) \\
\min -\max \end{array}$ & $\begin{array}{l}18.1 \\
(4.31) \\
7-30\end{array}$ & $\begin{array}{l}17.6 \\
(4.86) \\
8-29\end{array}$ & 0.43 \\
\hline Plant protein, servings/day ${ }^{b}$ & $0.41(0.67)$ & $0.46(0.56)$ & 0.61 \\
\hline Viscous fiber, servings/day ${ }^{b}$ & $1.38(1.17)$ & $1.28(1.35)$ & 0.56 \\
\hline Nuts, servings/day ${ }^{b}$ & $0.67(0.86)$ & $0.90(1.28)$ & 0.08 \\
\hline Phytosterols, mg/day b & $337(158)$ & $284(171)$ & 0.02 \\
\hline MUFAs, servings/day ${ }^{b}$ & $0.65(0.84)$ & $0.55(0.64)$ & 0.41 \\
\hline Saturated fat/cholesterol, servings/day $b$ & $2.48(1.82)$ & $2.89(2.26)$ & 0.13 \\
\hline
\end{tabular}

Data are shown as mean (SD) or $\mathrm{n}(\%)$ unless otherwise stated. Abbreviations: BMI, body mass index; CVD, cardiovascular disease; LDL-C, low-density lipoprotein cholesterol; MUFAs, monounsaturated fatty acids; PDS, Portfolio Diet score; y, year. ${ }^{a}$ More participants in the concurrent validation subsample had an unknown ethnicity as this information was not collected at the beginning of the study when the 7DDRs were completed; therefore, true differences may not exist. ${ }^{b}$ Dietary variables were assessed by baseline FFQ; intake of PDS and components based on specific food items listed in Table 1.

Table 3 reports the mean total servings/day (or mg/day) for each of the quintiles of the six components at baseline and six months within the predictive validation sample. At each time period, mean intakes increased at least four-fold across quintiles, and were highest for viscous fiber compared to other PDS components (3.24 and 4.77 servings/day at highest quintile). In contrast, plant protein, nuts and MUFA intakes were low 
(less than 1 serving/day) in all but the highest quintile where mean intakes ranged from 1-2 servings/day. At six months compared to baseline, greater servings/day of viscous fiber and plant protein (although small for plant protein) were observed, as well as phytosterols (mg/day). Fewer servings/day of saturated fat/cholesterol sources at six months were also observed, with little change in nut and MUFA intake.

Table 3. Mean daily intake of the Portfolio Diet components by quintile and assigned scores, assessed by FFQ at baseline and 6 months $(n=652)$.

\begin{tabular}{|c|c|c|c|c|c|c|c|c|c|c|}
\hline \multirow[b]{2}{*}{ Component } & \multicolumn{5}{|c|}{ Baseline } & \multicolumn{5}{|c|}{6 Months } \\
\hline & $\begin{array}{c}\text { Q1 } \\
\text { (1 Point) }\end{array}$ & $\begin{array}{c}\text { Q2 } \\
\text { (2 Points) }\end{array}$ & $\begin{array}{c}\text { Q3 } \\
\text { (3 Points) }\end{array}$ & $\begin{array}{c}\text { Q4 } \\
\text { (4 Points) }\end{array}$ & $\begin{array}{c}\text { Q5 } \\
\text { (5 Points) }\end{array}$ & $\begin{array}{c}\text { Q1 } \\
\text { (1 Point) }\end{array}$ & $\begin{array}{c}\mathrm{Q} 2 \\
\text { (2 Points) }\end{array}$ & $\begin{array}{c}\text { Q3 } \\
\text { (3 Points) }\end{array}$ & $\begin{array}{c}\text { Q4 } \\
\text { (4 Points) }\end{array}$ & $\begin{array}{c}\text { Q5 } \\
\text { (5 Points) }\end{array}$ \\
\hline $\begin{array}{l}\text { Plant protein, } \\
\text { servings/day }\end{array}$ & 0.03 & 0.11 & 0.19 & 0.43 & 1.31 & 0.05 & 0.15 & 0.37 & 0.75 & 1.59 \\
\hline $\begin{array}{l}\text { Viscous fiber, } \\
\text { servings/day }\end{array}$ & 0.25 & 0.66 & 1.08 & 1.59 & 3.24 & 0.51 & 1.17 & 1.74 & 2.60 & 4.77 \\
\hline $\begin{array}{c}\text { Nuts, } \\
\text { servings/day }\end{array}$ & 0.03 & 0.14 & 0.38 & 0.81 & 1.96 & 0.05 & 0.17 & 0.39 & 0.72 & 1.94 \\
\hline $\begin{array}{c}\text { Phytosterols, } \\
\text { mg/day }\end{array}$ & 164 & 240 & 310 & 389 & 587 & 182 & 274 & 354 & 443 & 690 \\
\hline $\begin{array}{c}\text { MUFAs, } \\
\text { servings/day }\end{array}$ & 0.02 & 0.12 & 0.40 & 0.82 & 2.03 & 0.02 & 0.14 & 0.45 & 0.83 & 2.07 \\
\hline $\begin{array}{c}\text { Saturated } \\
\text { fat/cholesterol } \\
\text { a, servings/day }\end{array}$ & 5.50 & 3.05 & 2.16 & 1.42 & 0.62 & 4.29 & 2.47 & 1.71 & 1.16 & 0.52 \\
\hline
\end{tabular}

Abbreviations: FFQ, food frequency questionnaire; MUFAs, monounsaturated fatty acids; Q, quintile. All components reported as servings/day except for phytosterols (mg/day). Intake of PDS components based on specific food items listed in Table 1. ${ }^{a}$ Higher quintiles represent higher intake; however, high intake and high quintiles of saturated fat/cholesterol received lower scores.

Table 4 shows the predictive validity results. Change in the PDS was inversely associated with change in LDL-C over six months, with a 1-point increase in score associated with a $-0.01 \mathrm{mmol} / \mathrm{L}(95 \%$ confidence intervals $(\mathrm{CI}):-0.02,-0.002 ; p=0.02)$ reduction in LDL-C. The odds of achieving a 5\% reduction in LDL-C was also $5 \%$ greater in those who had a 1-point change in the PDS over six months (95\% CIs: 1.01-1.10; $p=0.03$ ). The Pearson correlation coefficient between the change in the PDS and change in LDL-C was $-0.08(p=0.03)$.

Tables $5-7$ show the concurrent validity results. The median intake was higher on the FFQ for all PDS components except phytosterols and the saturated fat/cholesterol sources, which were higher in the 7DDR (Table 5). The median intake for total energy, carbohydrates, protein and fat was higher on the 7DDR than the FFQ (Table 6). The Pearson correlation coefficients for the overall PDS estimated from the FFQ were reasonably correlated with those from the 7DDR, and ranged from 0.66 to 0.69 for the crude, energy-adjusted and deattenuated coefficients (Table 5).

Table 4. Change in PDS and concomitant change in LDL-C from baseline to 6 months $(n=652)$.

\begin{tabular}{|c|c|c|c|c|c|c|}
\hline $\begin{array}{l}\text { LDL-C } \\
(\mathrm{mmol} / \mathrm{L})\end{array}$ & $\begin{array}{c}\text { Per 1-Unit Increase } \\
(\beta \text { Coefficients } \\
(95 \% \mathrm{CI}))\end{array}$ & $p$-Value & $\begin{array}{c}5 \% \text { Reduction in } \\
\text { LDL-C } \\
(\text { OR }(95 \% \text { CI }))\end{array}$ & $p$-Value & $\begin{array}{c}\text { Pearson Correlation } \\
\text { Coefficient }\end{array}$ & $p$-Value \\
\hline Model 1 * & $\begin{array}{c}-0.01 \\
(-0.02,-0.002)\end{array}$ & 0.02 & $\begin{array}{c}1.05 \\
(1.01-1.10)\end{array}$ & 0.01 & -0.08 & 0.03 \\
\hline
\end{tabular}

* Model 1 adjusted for sex, age, baseline LDL-C, energy intake, cholesterol-lowering medication use, ethnicity, BMI, smoking status, family history of CVD, education, physical activity, and intervention group. Intake of PDS based on specific food items listed in Table 1. 
Table 5. Daily absolute intake of the individual Portfolio Diet components and Pearson correlation coefficients between estimates by the baseline FFQ and 7DDR $(n=50)$.

\begin{tabular}{|c|c|c|c|c|c|}
\hline & FFQ & 7DDR & \multicolumn{3}{|c|}{ Pearson Correlation Coefficients } \\
\hline & $\begin{array}{c}\text { Median } \\
\text { (Min-Max) }\end{array}$ & $\begin{array}{c}\text { Median } \\
\text { (Min-Max) }\end{array}$ & $\begin{array}{l}\text { Unadjusted, } \\
\text { r (95\% CI) }\end{array}$ & $\begin{array}{l}\text { Energy-Adjusted, } \\
\text { r (95\% CI) }\end{array}$ & $\begin{array}{c}\text { Energy-Adjusted } \\
\text { and Deattenuated, } \\
\text { r }(95 \% \mathrm{CI})\end{array}$ \\
\hline $\begin{array}{l}\text { PDS, } \\
\text { points }\end{array}$ & $\begin{array}{c}17.6 \\
(8-29)\end{array}$ & $\begin{array}{c}17.0 \\
(9-28)\end{array}$ & $\begin{array}{c}0.66 \\
(0.47,0.80)\end{array}$ & $\begin{array}{c}0.65 \\
(0.45,0.79)\end{array}$ & $\begin{array}{c}0.69 \\
(0.48,0.85)\end{array}$ \\
\hline $\begin{array}{l}\text { Plant protein, } \\
\text { servings/day }\end{array}$ & $\begin{array}{c}0.19 \\
(0.00-2.85)\end{array}$ & $\begin{array}{c}0.17 \\
(0.00-2.77) \\
\end{array}$ & $\begin{array}{c}0.25 \\
(-0.03,0.49)\end{array}$ & $\begin{array}{c}0.25 \\
(-0.04,0.49)\end{array}$ & $\begin{array}{c}0.26 \\
(-0.04,0.52)\end{array}$ \\
\hline $\begin{array}{l}\text { Viscous fiber, } \\
\text { servings/day }\end{array}$ & $\begin{array}{c}0.88 \\
(0.05-6.93)\end{array}$ & $\begin{array}{c}0.53 \\
(0.00-2.23)\end{array}$ & $\begin{array}{c}0.42 \\
(0.15,0.62)\end{array}$ & $\begin{array}{c}0.40 \\
(0.14,0.61)\end{array}$ & $\begin{array}{c}0.44 \\
(0.15,0.67)\end{array}$ \\
\hline $\begin{array}{c}\text { Nuts, } \\
\text { servings/day }\end{array}$ & $\begin{array}{c}0.50 \\
(0.00-6.72)\end{array}$ & $\begin{array}{c}0.37 \\
(0.00-5.36) \\
\end{array}$ & $\begin{array}{c}0.40 \\
(0.14,0.61) \\
\end{array}$ & $\begin{array}{c}0.31 \\
(0.04,0.54)\end{array}$ & $\begin{array}{c}0.33 \\
(0.04,0.58) \\
\end{array}$ \\
\hline $\begin{array}{l}\text { Phytosterols, } \\
\text { mg/day }\end{array}$ & $\begin{array}{c}234 \\
(68-964) \\
\end{array}$ & $\begin{array}{c}316 \\
(108-780) \\
\end{array}$ & $\begin{array}{c}0.40 \\
(0.13,0.61) \\
\end{array}$ & $\begin{array}{c}0.59 \\
(0.38,0.75) \\
\end{array}$ & $\begin{array}{c}0.64 \\
(0.41,0.80) \\
\end{array}$ \\
\hline $\begin{array}{c}\text { MUFAs, } \\
\text { servings/day }\end{array}$ & $\begin{array}{c}0.44 \\
(0.00-3.29)\end{array}$ & $\begin{array}{c}0.29 \\
(0.00-2.10)\end{array}$ & $\begin{array}{c}0.30 \\
(0.02,0.53)\end{array}$ & $\begin{array}{c}0.26 \\
(-0.02,0.50)\end{array}$ & $\begin{array}{c}0.28 \\
(-0.02,0.55)\end{array}$ \\
\hline $\begin{array}{l}\text { Saturated } \\
\text { fat/cholesterol, } \\
\text { servings/day }\end{array}$ & $\begin{array}{c}2.25 \\
(0.08-10.9)\end{array}$ & $\begin{array}{c}3.37 \\
(0.08-7.44)\end{array}$ & $\begin{array}{c}0.37 \\
(0.10,0.59)\end{array}$ & $\begin{array}{c}0.37 \\
(0.10,0.59)\end{array}$ & $\begin{array}{c}0.41 \\
(0.11,0.65)\end{array}$ \\
\hline
\end{tabular}

Abbreviations: CI, confidence intervals; FFQ, food frequency questionnaire; MUFAs, monounsaturated fatty acids; PDS, Portfolio Diet score; 7DDR, 7-day diet record. Intake of PDS and components based on specific food items listed in Table 1. The individual PDS components were log-transformed.

The energy-adjusted and deattenuated correlation coefficients ranged from 0.26 to 0.64 for the individual six components, with plant protein (servings/day) having the weakest correlation and phytosterols (mg/day) having the strongest correlation. Table 6 shows the Pearson correlation coefficients for energy intake and macronutrients (total fat, protein and carbohydrates). The energy-adjusted and deattenuated correlation coefficients ranged from 0.34 to 0.64 , with energy intake (kcal/day) showing the weakest correlation and carbohydrates (g/day) showing the strongest correlation.

The PDS was then split into quartiles to further evaluate correlations and the ranking of participants by the FFQ and 7DDR (Table 7). The energy-adjusted and deattenuated Spearman correlation coefficients for quartiles of the PDS was 0.67 , similar to the absolute score correlation. In addition, $48 \%$ of individuals were ranked into the same quartile of the PDS on both diet assessment tools. The percentage of individuals in opposite quartiles on the FFQ and 7DDR was 0\%. The energy-adjusted and deattenuated Spearman correlation coefficients for quintiles of intake of the six components ranged from 0.36 to 0.54 , with the saturated fat/cholesterol and plant protein components having the weakest correlations, and phytosterols, MUFAs and nuts having the strongest correlations. On average, $32 \%$ of individuals were grouped into the same quintile on both diet tools (ranging from $24 \%$ for phytosterols and $38 \%$ for plant protein). Gross misclassification (percentage of individuals grouped in opposite quintiles) ranged from $0-4 \%$ for all components. 
Table 6. Daily absolute intake of the calories and macronutrients and Pearson correlation coefficients between estimates by the baseline FFQ and 7DDR $(n=50)$.

\begin{tabular}{|c|c|c|c|c|c|}
\hline & \multirow{2}{*}{$\begin{array}{c}\text { FFQ } \\
\begin{array}{c}\text { Median } \\
\text { (Min-Max) }\end{array}\end{array}$} & \multirow{2}{*}{$\begin{array}{c}\text { 7DDR } \\
\begin{array}{c}\text { Median } \\
\text { (Min-Max) }\end{array}\end{array}$} & \multicolumn{3}{|c|}{ Pearson Correlation Coefficients } \\
\hline & & & $\begin{array}{l}\text { Unadjusted, } \\
r(95 \% \mathrm{CI})\end{array}$ & $\begin{array}{l}\text { Energy-Adjusted, } \\
\quad r(95 \% \text { CI })\end{array}$ & $\begin{array}{c}\text { Energy-Adjusted } \\
\text { and Deattenuated, } \\
r(95 \% \mathrm{CI})\end{array}$ \\
\hline Energy, kcal/day & $\begin{array}{c}2049 \\
(744-4690)\end{array}$ & $\begin{array}{c}2114 \\
(1171-3729)\end{array}$ & $0.31(0.04,0.54)$ & - & $0.34(0.04,0.58)$ \\
\hline Carbohydrate, g/day & $\begin{array}{c}233 \\
(80-656)\end{array}$ & $\begin{array}{c}270 \\
(100-417)\end{array}$ & $0.31(0.03,0.54)$ & $0.59(0.37,0.75)$ & $0.64(0.40,0.81)$ \\
\hline Total protein, g/day & $\begin{array}{c}83 \\
(26-178) \\
\end{array}$ & $\begin{array}{c}94 \\
(54-180)\end{array}$ & $0.23(-0.05,0.48)$ & $0.38(0.11,0.59)$ & $0.41(0.12,0.65)$ \\
\hline Total fat, g/day & $\begin{array}{c}70 \\
(18-187)\end{array}$ & $\begin{array}{c}79 \\
(37-143)\end{array}$ & $0.42(0.15,0.62)$ & $0.53(0.29,0.70)$ & $0.57(0.31,0.76)$ \\
\hline
\end{tabular}

Abbreviations: CI, confidence intervals; FFQ, food frequency questionnaire; 7DDR, 7-day diet record.

Table 7. Correlation coefficients and agreement in the quantiles of the PDS and individual Portfolio Diet components between the baseline FFQ and 7DDR $(n=50)$.

\begin{tabular}{|c|c|c|c|c|c|}
\hline \multicolumn{6}{|c|}{ Spearman Correlation Coefficients } \\
\hline & $\begin{array}{l}\text { Unadjusted, } \\
r(95 \% \mathrm{CI})\end{array}$ & $\begin{array}{c}\text { Energy- } \\
\text { Adjusted, } \\
r(95 \% \text { CI) }\end{array}$ & $\begin{array}{c}\text { Energy- } \\
\text { Adjusted and } \\
\text { Deattenuated, } \\
r(95 \% \mathrm{CI})\end{array}$ & $\begin{array}{c}\text { Same Quantile }{ }^{\mathrm{a}}, \\
n(\%)\end{array}$ & $\begin{array}{c}\text { Opposite } \\
\text { Quantile }^{\mathrm{b}}, n(\%)\end{array}$ \\
\hline PDS & $\begin{array}{c}0.69 \\
(0.51,0.81) \\
\end{array}$ & $\begin{array}{c}0.65 \\
(0.45,0.79) \\
\end{array}$ & $\begin{array}{c}0.67 \\
(0.47,0.83) \\
\end{array}$ & $24(48)$ & $0(0)$ \\
\hline Plant protein & $\begin{array}{c}0.35 \\
(0.07,0.57)\end{array}$ & $\begin{array}{c}0.36 \\
(0.09,0.58)\end{array}$ & $\begin{array}{c}0.38 \\
(0.10,0.62)\end{array}$ & $19(38)$ & $1(2)$ \\
\hline Viscous fiber & $\begin{array}{c}0.44 \\
(0.18,0.64)\end{array}$ & $\begin{array}{c}0.39 \\
(0.13,0.60)\end{array}$ & $\begin{array}{c}0.42 \\
(0.14,0.64)\end{array}$ & $18(36)$ & $2(4)$ \\
\hline Nuts & $\begin{array}{c}0.58 \\
(0.36,0.74)\end{array}$ & $\begin{array}{c}0.49 \\
(0.25,0.68)\end{array}$ & $\begin{array}{c}0.53 \\
(0.27,0.73)\end{array}$ & $17(34)$ & $0(0)$ \\
\hline Phytosterols & $\begin{array}{c}0.43 \\
(0.18,0.64)\end{array}$ & $\begin{array}{c}0.51 \\
(0.27,0.69)\end{array}$ & $\begin{array}{c}0.54 \\
(0.29,0.73)\end{array}$ & $12(24)$ & $0(0)$ \\
\hline MUFAs & $\begin{array}{c}0.57 \\
(0.35,0.73)\end{array}$ & $\begin{array}{c}0.50 \\
(0.25,0.68)\end{array}$ & $\begin{array}{c}0.54 \\
(0.27,0.74)\end{array}$ & $18(36)$ & $1(2)$ \\
\hline Saturated fat/cholesterol & $\begin{array}{c}0.31 \\
(0.04,0.54)\end{array}$ & $\begin{array}{c}0.34 \\
(0.07,0.57)\end{array}$ & $\begin{array}{c}0.36 \\
(0.07,0.71)\end{array}$ & $13(26)$ & $0(0)$ \\
\hline
\end{tabular}

Abbreviations: CI, confidence intervals; FFQ, food frequency questionnaire; MUFAs, monounsaturated fatty acids; PDS, Portfolio Diet

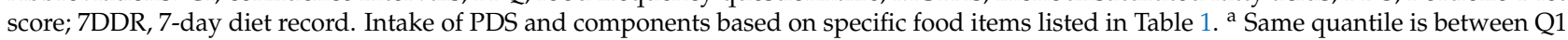
to Q4 for the PDS and Q1 and Q5 for the individual PDS components. ${ }^{\mathrm{b}}$ Opposite quantile is Q1 to Q4 for the PDS and Q1 to Q5 for the individual PDS components.

Figures 2 and S1-S10 show the Bland-Altman plots to assess mean agreement between the FFQ and 7DDR estimates for absolute intake of the PDS, its six PDS components, energy, total fat, protein and carbohydrate. In general, the Bland-Altman plots showed good agreement for the PDS, all PDS components and macronutrients assessed. Although the mean difference between the two dietary methods was close to 0 for the PDS and its individual components, the FFQ appeared to slightly overestimate 4 of the 6 components (plant protein, viscous fiber, nuts, MUFAs) and underestimate phytosterols and saturated fat, compared to the 7DDR (Figures S6-S10). There also appeared to be better agreement at lower intake than higher intake as evidenced by a clustering of data at low intake and a greater scatter at high intake for the plant protein, nuts, viscous fiber and MUFAs Bland-Altman plots; however, this finding needs to be interpreted with caution as low 
consumption of these foods in both the FFQ and 7DDR cannot have a large difference between the two diet assessment methods (Figures S6-S9).

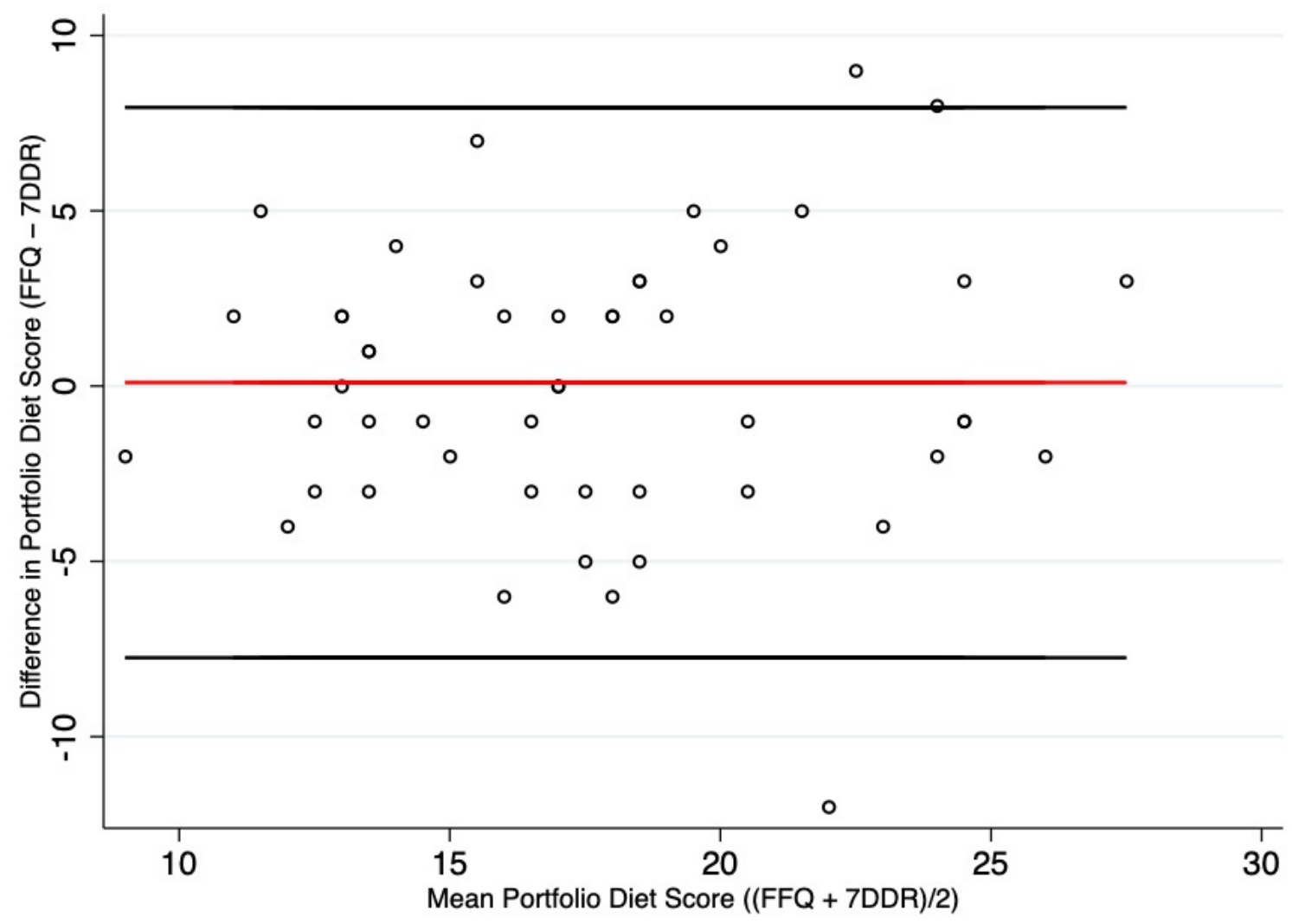

Figure 2. Mean differences of the PDS derived from the FFQ and 7DDR. Abbreviations: FFQ, food frequency questionnaire; 7DDR, 7-day diet record. Solid black lines are the upper and lower 95\% LOA (-7.75 to 7.94). Red line is the mean difference (0.10).

\section{Discussion}

The current study developed a PDS and assessed its predictive $(n=652)$ and concurrent validity $(n=50)$ by comparing intake estimates from an FFQ to LDL-C and a 7DDR among overweight adults in Toronto. We developed a mainly food-based PDS based on populationspecific intake using quintile cut-offs and with equal weight for each component of the score. We observed that the change in the PDS was inversely associated with a reduction in LDL-C and with the odds of achieving a 5\% reduction in LDL-C over six months. Compared with data from a 7DDR, the FFQ showed reasonable concurrent validity and agreement to rank participants on the overall PDS, with a moderately high energy-adjusted and deattenuated correlation coefficient of 0.69 .

There was also acceptable validity and agreement between the 7DDR and FFQ for most absolute intakes of individual components of the PDS, energy and macronutrients; however, correlation coefficients were poor (below 0.3) for plant protein and MUFAs and only slightly better for nuts $(r=0.33)$ [55]. There was also a small overestimation of several Portfolio Diet components by the FFQ compared to the 7DDR, particularly at higher intake. The lower correlation coefficients for plant protein, MUFAs, and nuts suggest that intake of these components may be more difficult to estimate on the FFQ than with a 7DDR compared to the other components. Alternatively, it is possible that these components were better assessed by the FFQ as they may be more episodically consumed (i.e., not daily) than the other components, and the 7DDR may not have captured the specific days when these components were consumed [56]. Additionally, quintiles of intake resulted in correlation coefficients that were $>0.1$ higher than those based on absolute intake 
but only for these same components (plant protein, nuts and MUFAs). Therefore, these potentially episodically consumed components may be better assessed by ranking since mean consumption in all but the highest quintile was low (less than 1 serving/day), there was better agreement at low intakes between the FFQ and the 7DDR, and any discordant assessment between the methods at higher intakes may not have substantially reduced the ability to rank participants' consumption of these components.

During the development phase of our PDS, we observed that basing the score cutoffs on quintiles rather than medians resulted in significant inverse associations with LDL-C. This finding is in line with our hypothesis and previous literature that has shown that loss of information is reduced with four or five groups and diagnostic accuracy is improved by providing better discriminating power to detect differences in health outcomes $[35,57,58]$. We also observed that providing more weight to the low saturated fat/cholesterol component did not change the association with LDL-C. Many other diet scores have not reported or examined weighting of their score components, and most provide equal weight to each score component $[24,31,34]$.

To the best of our knowledge, this is the first PDS created in the literature; therefore, a direct comparison of our score with other validation studies is not possible. Studies evaluating the predictive validity of other dietary patterns with blood lipids such as cholesterol do exist, however, but are limited. The prudent [59], Healthy Eating Index (HEI) [60,61], Diet Quality Index Revised (DQI-R) [62], and the plant-based diet indices [63] have been evaluated for associations with total cholesterol (TC) and/or LDL-C; however, most studies reported TC only. The prudent dietary pattern determined by principal component analysis and intake data from a 131-item Willet FFQ used with 127 men from the Health Professionals Follow-up Study (HPFS) was reported to have Pearson correlation coefficients with TC ranging from -0.08 to -0.12 , which is similar to our LDL-C correlation coefficient of -0.08 [59]. Furthermore, DQI-R scores using the same 131-item Willet FFQ and in the HPFS cohort, were inversely correlated with TC $(r=-0.22)$ [62]. In contrast, no significant correlations between HEI scores determined from a three-day diet record and TC concentrations were found in a validation study of 340 women from the University of Michigan Hospital's Breast Care Center [61]. Likewise, no significant correlations were found between the plant-based diet indices determined from a 152-item Willett FFQ and TC in 720 women and 634 men from the Women's and Men's Lifestyle Validation Studies of the HPFS and Nurses Health Studies I and II [63]. Correlation coefficients were assessed between the HEI score from a 24-h dietary recall and LDL-C levels in a subsequent validation study in 6979 men and women from the National Health and Nutrition Examination Survey (NHANES) III, and small but also significant correlation coefficients $(r=-0.04)$ were seen [60]. This NHANES validation study only collected one day of intake from participants; therefore, intake may have been underestimated [64]. Our study saw significant inverse correlations between change in the PDS and change in LDL-C, which is the main target of the Portfolio Diet, and may also explain why we saw significant relationships with this CVD risk factor and some of the other validation studies did not.

For the concurrent validation, data on dietary patterns is also scarce. As discussed previously, the prudent and Western dietary patterns derived from principal component analysis in the HPFS cohort had energy-adjusted and deattenuated correlation coefficients between the FFQ and two 1-week diet records that ranged from 0.45 to 0.74 [59]. Similar deattenuated correlation coefficients ( 0.41 to 0.73 ) between a 60 -item FFQ and four 1week diet records were also found for the prudent, Western and other dietary patterns derived from principal component analysis in 111 women from the Swedish Mammography cohort [65]. Our finding of an energy-adjusted and deattenuated correlation coefficient $(r=0.69)$ for the PDS is within the range reported in these two studies. Of more direct relevance to our PDS, a validation study of the plant-based diet indices found energyadjusted and deattenuated correlation coefficients between the indices from a 152-item Willet FFQ and two 1-week diet records ranging from 0.62 to 0.67 , which are also similar to our findings [63]. A further study assessed the validity of two modified Mediterranean 
diet scores, based on tertile distribution of food consumption, in 107 men and women from the REGICOR study in Spain [66]. The energy-adjusted and deattenuated correlation coefficients between a 166-item FFQ and ten 24-h recalls for both Mediterranean diet scores ranged from 0.48 to 0.61 , which is slightly weaker, but similar, to our findings. In addition, they found reasonable agreement and gross misclassification through their Bland-Altman and opposite quantile analysis, also in line with our results [66]. Both their modified Mediterranean diet score (score range 10-30) and the Mediterranean-like diet score (score range 13-39) had limits of agreement (LOA) that ranged from -7 to +7 in Bland-Altman plots comparing mean intakes from the FFQ and multiple 24-h recalls. Additionally, our LOAs were well within the boundaries of $50 \%-200 \%$, identified by these and other authors as being reasonable $[66,67]$. Overall, our study and other literature are in agreement that dietary patterns assessed through the use of FFQs provide reasonably valid measures of intake and ranking compared to multiple days of diet records or 24-h recalls.

Energy-adjusted and deattenuated correlation coefficients for the six individual Portfolio Diet components ranged from $0.26-0.64$ for absolute intakes (servings/day or $\mathrm{mg} /$ day) and $0.36-0.54$ for quintile rankings (1-5) in our study, which is comparable to the results of absolute intakes in other studies where similar groupings to our PDS were available $[45,66,68]$. Of particular interest is the phytosterol component, as this was a new nutrient added to the FFQ and 7DDR data in our study. Phytosterols showed correlation coefficients of 0.54 for rank in quintiles and a correlation coefficient of 0.64 for absolute intake, both indicating reasonable validity. These results are consistent with a previous study that estimated the phytosterol intake from a 178-item FFQ against twelve 24-h recalls in the EPIC-Netherlands cohort. The researchers reported an energy-adjusted correlation coefficient of 0.59 between the two methods [45]. Further research assessed the energyadjusted and deattenuated correlation coefficients and agreement between the individual components of a Mediterranean diet score [66]. Food categories similar to ours included nuts, legumes and olive oil, where correlation coefficients of absolute intakes obtained through a 166-item FFQ and 24-h recalls were $0.36,0.25$ and 0.33 , respectively [66]. These results are in line with the correlation coefficients we found with absolute intakes of nuts (0.33), plant protein (0.26) and MUFAs (0.28). For the misclassification analysis in the Mediterranean diet score study, more participants were in either the same or opposite tertiles to our study [66]. This discrepancy may be related to analyzing tertiles instead of quintiles of intake, as quintiles provide a larger range of options to classify participants. Additionally, Feskanich et al. (1993) conducted a foods validation study using a 131-item Willet FFQ in 127 men from the HPFS where observed energy-adjusted and deattenuated correlations between two 1-week diet records and the FFQs were 0.72 for peanut butter, 0.17 for other nuts, 0.34 for beans/lentils and 0.56 for tofu/soybeans [68]. These correlations are generally stronger than those for similar food components in our study; however, our nut component $(r=0.33)$ included both peanut butter and other nuts, and our plant protein component $(\mathrm{r}=0.26)$ combined beans/lentils and tofu/soy foods and are therefore not directly comparable. Nonetheless, the stronger correlation coefficients observed in the previous study may be explained by the larger sample size and greater number of diet records in their study compared to ours.

Strengths of our study include the various assessments conducted when developing the score, as well as the use of multiple methods to assess the validity and agreement between the two diet assessment tools. We assessed the scores ability to predict changes in LDL-C and correlation with LDL-C, the main target of the Portfolio Diet. Using change in LDL-C, rather than baseline LDL-C as assessed in other validation studies, is also a strength as variability due to individual genetic or other determinants is removed [69]. We also assessed concurrent validity of the PDS using correlation coefficients, Bland-Altman plots and cross-classification. All methods showed reasonable validity of the FFQ to assess the PDS, compared to a 7DDR, in overweight adults. Another strength of our study is the addition of relevant foods to the FFQ to better capture adherence to the Portfolio Diet. Additional questions on other high MUFA sources would have further strengthened our 
ability to assess adherence to this component of the diet. For example, we were not able to quantify total olive oil intake and questions on other high MUFA oils, such as canola or sunflower, were not included on the FFQ.

Nevertheless, there are limitations to the present study. We used a 7DDR as the reference method, which is also a self-reported diet assessment method; therefore, it is not error free and errors between the FFQ and 7DDR may be correlated. Ideally, the 7DDR would have been weighed diet records with more than seven days of recording. On the other hand, the FFQ asked about usual intake over the past month. Therefore, seven days may be reasonable for this time frame. However, non-consecutive days would have better captured within-person variation [69] and may have resulted in stronger correlations for potential episodically consumed foods such as plant protein. It is also important to note that our sample size $(n=50)$ for the concurrent validation analysis is small, and preferably would have been larger and had adequate numbers of males and females [69]. We were unable to examine sex differences due to the small sample size and because our population was mostly female ( $76 \%$ for predictive and $62 \%$ for concurrent validation analyses). The population also included overweight adults and therefore the results may not be applicable to the general population. Lastly, the correlation between increasing PDS with lower LDL-C was not overly strong, and we would expect stronger correlations if intake of the individual Portfolio Diet components were higher in this population. The reductions in LDL-C were likely driven by increased intake of the more commonly consumed foods containing viscous fiber and phytosterols, and decreased intake of saturated fat/cholesterol sources over the six months. In general, there was limited consumption of plant protein, nuts and MUFAs in the current study, except among those in the highest quintiles of intake, which is in agreement with more recent data from the 2015 Canadian Community Health Survey, where nuts, seeds and legumes only contributed $5 \%$ of total protein intake [70]. Greater intake of the Portfolio Diet components would likely have resulted in stronger inverse correlations with LDL-C.

Future studies that use our PDS, which is based on population-specific cut-offs, will need to consider that intake of the six individual components and results may vary largely among populations. The inclusion of more ethnically diverse populations or vegetarians may also improve the examination of PDS food components that were minimally consumed in this study (e.g., plant proteins, nuts). Comparison of dietary intake across populations will help determine the level of Portfolio Diet adherence that is associated with a lower risk of disease outcomes. Lastly, whether the PDS can predict disease incidence in diverse populations will be a critical assessment of its validity. To date, we have assessed our PDS in an overweight/obese population with metabolic syndrome in the PREDIMED-Plus clinical trial cohort and with incident CVD outcomes in postmenopausal women in the Women's Health Initiative (WHI). Greater adherence to our PDS was significantly associated with lower $\mathrm{HbA1c}$, fasting plasma glucose, triglycerides, BMI and waist circumference over one year in PREDIMED-Plus [17], and was significantly associated with a lower risk of CVD, coronary heart disease and heart failure in the WHI [18]. These two studies provide further evidence that the PDS can predict improvements in several cardiometabolic risk factors and diseases.

\section{Conclusions}

The PDS predicts lower LDL-C and shows reasonable concurrent validity over six months in overweight adults. Future studies are needed to examine diet-disease relationships in prospective cohort studies and whether the PDS can further reliably predict clinical disease outcomes, such as lower CVD risk. 
Supplementary Materials: The following are available online at https: / www.mdpi.com/article/ 10.3390/nu13082850/s1, Table S1: Estimated mean ABSOLUTE intakes for the PDS components for Q1 through Q5 from the FFQ at baseline and 6 months compared to the Portfolio Diet trial recommendations $(n=652)$, Table S2: Inter-item correlations between the individual Portfolio Diet components contributing to the PDS $(n=652)$, Figure S1: Mean differences of the total energy intake (kcal/day) derived from the FFQ and 7DDR $(n=50)$, Figure S2: Mean differences of the carbohydrate intake (g/day) derived from the FFQ and 7DDR $(n=50)$, Figure S3: Mean differences of total protein intake (g/day) derived from the FFQ and 7DDR $(n=50)$, Figure S4: Mean differences of the total fat intake (g/day) derived from the FFQ and 7DDR $(n=50)$, Figure S5: Mean differences of plant protein (servings/day) derived from the FFQ and 7DDR $(n=50)$, Figure S6: Mean differences of viscous fiber (servings/day) derived from the FFQ and 7DDR $(n=50)$, Figure S7: Mean differences of nuts (servings/day) derived from the FFQ and 7DDR $(n=50)$, Figure S8: Mean differences of phytosterols (mg/day) derived from the FFQ and 7DDR $(n=50)$, Figure S9: Mean differences of MUFAs (servings/day) derived from the FFQ and 7DDR $(n=50)$, Figure S10: Mean differences of Saturated Fat/Cholesterol (servings/day) derived from the FFQ and 7DDR $(n=50)$.

Author Contributions: Conceptualization, A.J.G., B.A.B., A.J.H., D.J.A.J., J.L.S.; FFQ modifications, B.A.B., D.J.A.J.; Dietary data collection, B.A.B., A.J.H., D.J.A.J., M.P.; Dietary data entry and analysis: A.J.G., C.C.K.; Statistical analysis, A.J.G., T.A.K.; Writing-original draft preparation, A.J.G., B.A.B.; Supervision, B.A.B., J.L.S. All authors provided interpretation of the data and critical revision of the manuscript for intellectual content. All authors have read and agreed to the published version of the manuscript.

Funding: The Toronto Healthy Diet Study was supported by the Canadian Institutes of Health Research (CIHR) and Loblaws Cos. Ltd. A.J.G. was supported by the Nora Martin Fellowship in Nutritional Sciences, the Banting and Best Diabetes Centre Tamarack Graduate Award in Diabetes Research, the Peterborough K.M. Hunter Charitable Foundation Graduate Award and an Ontario Graduate Scholarship. D.J.A.J. was funded by the Government of Canada through the Canada Research Chair Endowment. J.L.S. was funded by a PSI Graham Farquharson Knowledge Translation Fellowship, Diabetes Canada Clinician Scientist Award, CIHR INMD/CNS New Investigator Partnership Prize, and Banting \& Best Diabetes Centre Sun Life Financial New Investigator Award.

Institutional Review Board Statement: The study was conducted in accordance with the Declaration of Helsinki and approved by the Research Ethics boards of the University of Toronto (REB\#22575) and St. Michael's Hospital (REB\#04-016).

Informed Consent Statement: Informed consent was obtained from all participants involved in the study.

Data Availability Statement: Data is contained within the article.

Conflicts of Interest: A.J.G. has received consulting fees from SoLo GI Nutrition and an honorarium from the Soy Nutrition Institute (SNI). T.A.K. has received research support from the Canadian Institutes of Health Research (CIHR), the International Life Science Institute (ILSI), and the National Honey Board. A.J.H. received independent investigator-initiated research funding from Dairy Farmers of Canada. C.W.C.K. has received grants or research support from the Advanced Food Materials Network, Agriculture and Agri-Foods Canada (AAFC), Almond Board of California, Barilla, Canadian Institutes of Health Research (CIHR), Canola Council of Canada, International Nut and Dried Fruit Council, International Tree Nut Council Research and Education Foundation, Loblaw Brands Ltd., the Peanut Institute, Pulse Canada and Unilever. He has received in-kind research support from the Almond Board of California, Barilla, California Walnut Commission, Kellogg Canada, Loblaw Companies, Nutrartis, Quaker (PepsiCo), the Peanut Institute, Primo, Unico, Unilever, WhiteWave Foods/Danone. He has received travel support and/or honoraria from the Barilla, California Walnut Commission, Canola Council of Canada, General Mills, International Nut and Dried Fruit Council, International Pasta Organization, Lantmannen, Loblaw Brands Ltd., Nutrition Foundation of Italy, Oldways Preservation Trust, Paramount Farms, the Peanut Institute, Pulse Canada, Sun-Maid, Tate \& Lyle, Unilever and White Wave Foods/Danone. He has served on the scientific advisory board for the International Tree Nut Council, International Pasta Organization, McCormick Science Institute and Oldways Preservation Trust. He is a founding member of the International Carbohydrate Quality Consortium (ICQC), Executive Board Member of the Diabetes and Nutrition Study Group (DNSG) of the European Association for the Study of Diabetes (EASD), is on the Clinical Practice Guidelines Expert Committee for Nutrition Therapy of the EASD and 
is a Director of the Toronto 3D Knowledge Synthesis and Clinical Trials foundation. D.J.A.J. has received research grants from Saskatchewan \& Alberta Pulse Growers Associations, the Agricultural Bioproducts Innovation Program through the Pulse Research Network, the Advanced Foods and Material Network, Loblaw Companies Ltd., Unilever Canada and Netherlands, Barilla, the Almond Board of California, Agriculture and Agri-food Canada, Pulse Canada, Kellogg's Company, Canada, Quaker Oats, Canada, Procter \& Gamble Technical Centre Ltd., Bayer Consumer Care, Springfield, NJ, Pepsi/Quaker, International Nut \& Dried Fruit Council (INC), Soy Foods Association of North America, the Coca-Cola Company (investigator initiated, unrestricted grant), Solae, Haine Celestial, the Sanitarium Company, Orafti, the International Tree Nut Council Nutrition Research and Education Foundation, the Peanut Institute, Soy Nutrition Institute (SNI), the Canola and Flax Councils of Canada, the Calorie Control Council, the Canadian Institutes of Health Research (CIHR), the Canada Foundation for Innovation (CFI)and the Ontario Research Fund. (ORF). He has received in-kind supplies for trials as a research support from the Almond board of California, Walnut Council of California, the Peanut Institute, Barilla, Unilever, Unico, Primo, Loblaw Companies, Quaker (Pepsico), Pristine Gourmet, Bunge Limited, Kellogg Canada, WhiteWave Foods. He has been on the speaker's panel, served on the scientific advisory board and/or received travel support and/or honoraria from 2020 China Glycemic Index (GI) International Conference, Atlantic Pain Conference, Academy of Life Long Learning, the Almond Board of California, Canadian Agriculture Policy Institute, Loblaw Companies Ltd., the Griffin Hospital (for the development of the NuVal scoring system), the Coca-Cola Company, Epicure, Danone, Diet Quality Photo Navigation (DQPN), Better Therapeutics (FareWell), Verywell, True Health Initiative (THI), Heali AI Corp, Institute of Food Technologists (IFT), Soy Nutrition Institute (SNI), Herbalife Nutrition Institute (HNI), Saskatchewan \& Alberta Pulse Growers Associations, Sanitarium Company, Orafti, the International Tree Nut Council Nutrition Research and Education Foundation, the Peanut Institute, Herbalife International, Pacific Health Laboratories, Nutritional Fundamentals for Health (NFH), Barilla, Metagenics, Bayer Consumer Care, Unilever Canada and Netherlands, Solae, Kellogg, Quaker Oats, Procter \& Gamble, Abbott Laboratories, Dean Foods, the California Strawberry Commission, Haine Celestial, PepsiCo, the Alpro Foundation, Pioneer Hi-Bred International, DuPont Nutrition and Health, Spherix Consulting and WhiteWave Foods, the Advanced Foods and Material Network, the Canola and Flax Councils of Canada, Agri-Culture and Agri-Food Canada, the Canadian Agri-Food Policy Institute, Pulse Canada, the Soy Foods Association of North America, the Nutrition Foundation of Italy (NFI), Nutra-Source Diagnostics, the McDougall Program, the Toronto Knowledge Translation Group (St. Michael's Hospital), the Canadian College of Naturopathic Medicine, The Hospital for Sick Children, the Canadian Nutrition Society (CNS), the American Society of Nutrition (ASN), Arizona State University, Paolo Sorbini Foundation and the Institute of Nutrition, Metabolism and Diabetes. He received an honorarium from the United States Department of Agriculture to present the 2013 W.O. Atwater Memorial Lecture. He received the 2013 Award for Excellence in Research from the International Nut and Dried Fruit Council. He received funding and travel support from the Canadian Society of Endocrinology and Metabolism to produce mini cases for the Canadian Diabetes Association (CDA). He is a member of the International Carbohydrate Quality Consortium (ICQC). His wife, Alexandra L Jenkins, is a director and partner of INQUIS Clinical Research for the Food Industry, his 2 daughters, Wendy Jenkins and Amy Jenkins, have published a vegetarian book that promotes the use of the foods described here, The Portfolio Diet for Cardiovascular Risk Reduction (Academic Press/Elsevier 2020 ISBN:978-0-12-810510-8)and his sister, Caroline Brydson, received funding through a grant from the St. Michael's Hospital Foundation to develop a cookbook for one of his studies. J.L.S. has received research support from the Canadian Foundation for Innovation, Ontario Research Fund, Province of Ontario Ministry of Research and Innovation and Science, Canadian Institutes of health Research (CIHR), Diabetes Canada, PSI Foundation, Banting and Best Diabetes Centre (BBDC), American Society for Nutrition (ASN), INC International Nut and Dried Fruit Council Foundation, National Dried Fruit Trade Association, National Honey Board (the U.S. Department of Agriculture [USDA] honey "Checkoff" program), International Life Sciences Institute (ILSI), Pulse Canada, Quaker Oats Center of Excellence, The United Soybean Board (the USDA soy "Checkoff" program), The Tate and Lyle Nutritional Research Fund at the University of Toronto, The Glycemic Control and Cardiovascular Disease in Type 2 Diabetes Fund at the University of Toronto (a fund established by the Alberta Pulse Growers), and The Nutrition Trialists Fund at the University of Toronto (a fund established by an inaugural donation from the Calorie Control Council). He has received in-kind food donations to support a randomized controlled trial from the Almond Board of California, California Walnut Commission, Peanut Institute, 
Barilla, Unilever/Upfield, Unico/Primo, Loblaw Companies, Quaker, Kellogg Canada, WhiteWave Foods/Danone, and Nutrartis. He has received travel support, speaker fees and/or honoraria from Diabetes Canada, Dairy Farmers of Canada, FoodMinds LLC, International Sweeteners Association, Nestlé, Pulse Canada, Canadian Society for Endocrinology and Metabolism (CSEM), GI Foundation, Abbott, General Mills, Biofortis, ASN, Northern Ontario School of Medicine, INC Nutrition Research \& Education Foundation, European Food Safety Authority (EFSA), Comité Européen des Fabricants de Sucre (CEFS), Nutrition Communications, International Food Information Council (IFIC), Calorie Control Council, International Glutamate Technical Committee, and Physicians Committee for Responsible Medicine. He has or has had ad hoc consulting arrangements with Perkins Coie LLP, Tate \& Lyle, Wirtschaftliche Vereinigung Zucker e.V., Danone, and Inquis Clinical Research. He is a member of the European Fruit Juice Association Scientific Expert Panel and former member of the Soy Nutrition Institute (SNI) Scientific Advisory Committee. He is on the Clinical Practice Guidelines Expert Committees of Diabetes Canada, European Association for the study of Diabetes (EASD), Canadian Cardiovascular Society (CCS), and Obesity Canada/Canadian Association of Bariatric Physicians and Surgeons. He serves or has served as an unpaid scientific advisor for the Food, Nutrition, and Safety Program (FNSP) and the Technical Committee on Carbohydrates of ILSI North America. He is a member of the International Carbohydrate Quality Consortium (ICQC), Executive Board Member of the Diabetes and Nutrition Study Group (DNSG) of the EASD, and Director of the Toronto 3D Knowledge Synthesis and Clinical Trials foundation. His wife is an employee of AB InBev. All other authors declare no conflicts.

\section{References}

1. Jenkins, D.J.; Kendall, C.W.; Faulkner, D.; Vidgen, E.; Trautwein, E.A.; Parker, T.L.; Marchie, A.; Koumbridis, G.; Lapsley, K.G.; Josse, R.G.; et al. A dietary portfolio approach to cholesterol reduction: Combined effects of plant sterols, vegetable proteins, and viscous fibers in hypercholesterolemia. Metabolism 2002, 51, 1596-1604. [CrossRef]

2. Health Canada, Food Directorate Health Products and Food Branch. Plant Sterols and Blood Cholesterol Lowering. Available online: https: / /www.canada.ca/en/health-canada/services/food-nutrition/foodlabelling/health-claims/assessments/plantsterols-blood-cholesterol-loweringnutrition-health-claims-food-labelling.html (accessed on 3 February 2021).

3. Health Canada, Food Directorate Health Products and Food Branch. Oat Products and Blood Cholesterol Lowering. Available online: https:/ / www.canada.ca/en/health-canada/services/food-nutrition/food-labelling/health-claims/assessments / products-blood-cholesterol-lowering-summary-assessment-health-claim-about-products-blood-cholesterol-lowering.html (accessed on 3 February 2021).

4. Health Canada, Food Directorate Health Products and Food Branch, H.C. Summary of Health Canada's Assessment of a Health Claim About Soy Protein and Cholesterol Lowering. Available online: https://www.canada.ca/en/health-canada/services/ food-nutrition/food-labelling/health-claims/assessments/summary-assessment-health-claim-about-protein-cholesterollowering.html (accessed on 3 February 2021).

5. Health Canada, Food Directorate Health Products and Food Branch. List of Dietary Fibres Reviewed and Accepted by Health Canada's Food Directorate. Available online: https:/ /www.canada.ca/en/healthcanada/services/publications/food-nutrition/ list-reviewed-accepted-dietary-fibres.html (accessed on 3 February 2021).

6. U.S Food \& Drug Administration. Qualified Health Claims: Letter of Enforcement Discretion-Nuts and Coronary Heart Disease. Available online: http://wayback.archive-it.org/7993/20171114183724/https://www.fda.gov/Food/ IngredientsPackagingLabeling/LabelingNutrition/ucm072926.htm (accessed on 3 February 2021).

7. U.S. Food \& Drug Administration. Health Claims: Soy Protein and Risk of Coronary Heart Disease. Available online: https: //www.accessdata.fda.gov/scripts/cdrh/cfdocs/cfcfr/cfrsearch.cfm?fr=101.82 (accessed on 3 February 2021).

8. EFSA Panel on Dietetic Products, Nutrition and Allergies. Scientific Opinion on the Substantiation of a Health Claim Related to oat Betaglucan and Lowering Blood Cholesterol and Reduced Risk of (Coronary) Heart Disease Pursuant to Article 14 of Regulation (EC) No 1924/2006. EFSA J. 2010, 8, 1885. Available online: www.efsa.europa.eu/efsajournal.htm (accessed on 3 February 2021).

9. EFSA Panel on Dietetic Products, Nutrition and Allergies. Scientific Opinion on the Substantiation of a Health Claimrelated to 3 g/day Plant Sterols/Stanols and Lowering Blood LDL-Cholesterol and Reduced Risk of (Coronary) Heart Disease Pursuant to Article 19 of Regulation (EC) No 1924/2006. EFSA J. 2012, 10, 2693. Available online: https://www.efsa.europa.eu/en/ publications (accessed on 3 February 2021). [CrossRef]

10. Expert Panel on Detection, Evaluation, and Treatment of High Blood Cholesterol in Adults. Executive Summary of the Third Report of the National Cholesterol Education Program (NCEP) Expert Panel on Detection, Evaluation, and Treatment of High Blood Cholesterol in Adults (Adult Treatment Panel III). JAMA 2001, 285, 2486-2497. [CrossRef] [PubMed]

11. Jenkins, D.J.A.; Kendall, C.W.C.; Marchie, A.; Faulkner, D.; Vidgen, E.; Lapsley, K.G.; Trautwein, E.A.; Parker, T.L.; Josse, R.G.; Leiter, L.A.; et al. The effect of combining plant sterols, soy protein, viscous fibers, and almonds in treating hypercholesterolemia. Metabolism 2003, 52, 1478-1483. [CrossRef] 
12. Jenkins, D.J.A.; Kendall, C.W.C.; Marchie, A.; Faulkner, D.A.; Wong, J.M.W.; de Souza, R.; Emam, A.; Parker, T.L.; Vidgen, E.; Lapsley, K.G.; et al. Effects of a Dietary Portfolio of Cholesterol-Lowering Foods vs Lovastatin on Serum Lipids and C-Reactive Protein. JAMA 2003, 290, 502-510. [CrossRef]

13. Jenkins, D.J.A.; Kendall, C.W.C.; Faulkner, D.A.; Nguyen, T.; Kemp, T.; Marchie, A.; Wong, J.M.W.; de Souza, R.; Emam, A.; Vidgen, E.; et al. Assessment of the longer-term effects of a dietary portfolio of cholesterol-lowering foods in hypercholesterolemia. Am. J. Clin. Nutr. 2006, 83, 582-591. [CrossRef]

14. Jenkins, D.J.A.; Jones, P.; Lamarche, B.; Kendall, C.W.C.; Faulkner, D.; Cermakova, L.; Gigleux, I.; Ramprasath, V.; de Souza, R.; Ireland, C.; et al. Effect of a Dietary Portfolio of Cholesterol-Lowering Foods Given at 2 Levels of Intensity of Dietary Advice on Serum Lipids in Hyperlipidemia. JAMA 2011, 306, 831-839. [CrossRef]

15. Jenkins, D.J.; Chiavaroli, L.; Wong, J.M.; Kendall, C.; Lewis, G.F.; Vidgen, E.; Connelly, P.W.; Leiter, L.A.; Josse, R.G.; Lamarche, B. Adding monounsaturated fatty acids to a dietary portfolio of cholesterol-lowering foods in hypercholesterolemia. Can. Med. Assoc. J. 2010, 182, 1961-1967. [CrossRef]

16. Chiavaroli, L.; Nishi, S.K.; Khan, T.A.; Braunstein, C.R.; Glenn, A.J.; Mejia, S.B.; Rahelić, D.; Kahleová, H.; Salas-Salvadó, J.; Jenkins, D.J.; et al. Portfolio Dietary Pattern and Cardiovascular Disease: A Systematic Review and Meta-analysis of Controlled Trials. Prog. Cardiovasc. Dis. 2018, 61, 43-53. [CrossRef]

17. Glenn, A.J.; Hernández-Alonso, P.; Kendall, C.W.; Martínez-González, M.Á.; Corella, D.; Fitó, M.; Martínez, J.; Alonso-Gómez, Á.M.; Wärnberg, J.; Vioque, J.; et al. Longitudinal changes in adherence to the portfolio and DASH dietary patterns and cardiometabolic risk factors in the PREDIMED-Plus study. Clin. Nutr. 2021, 40, 2825-2836. [CrossRef]

18. Glenn, A.J.; Lo, K.; Jenkins, D.J.A.; Boucher, B.A.; Hanley, A.J.; Kendall, C.W.C.; Manson, J.E.; Vitolins, M.Z.; Snetselaar, L.G.; Liu, S.; et al. Relationship Between a Plant-Based Dietary Portfolio and Risk of Cardiovascular Disease: Findings from the Women's Health Initiative Prospective Cohort Study. J. Am. Heart Assoc. 2021, e021515. [CrossRef]

19. Kirkpatrick, S.I.; Vanderlee, L.; Raffoul, A.; Stapleton, J.; Csizmadi, I.; Boucher, B.; Massarelli, I.; Rondeau, I.; Robson, P.J. Self-Report Dietary Assessment Tools Used in Canadian Research: A Scoping Review. Adv. Nutr. 2017, 8, 276-289. [CrossRef]

20. Jenkins, D.J.; Boucher, B.; Ashbury, F.D.; Sloan, M.; Brown, P.; El-Sohemy, A.; Hanley, A.J.; Willett, W.; Paquette, M.; de Souza, R.J.; et al. Effect of Current Dietary Recommendations on Weight Loss and Cardiovascular Risk Factors. J. Am. Coll. Cardiol. 2017, 69, 1103-1112. [CrossRef] [PubMed]

21. Health Canada. History of Canada's Food Guides from 1942 to 2007. Available online: https:/ /www.canada.ca/en/healthcanada/services/canada-food-guide/about/history-food-guide.html (accessed on 12 April 2021).

22. Willett, W.C.; Sampson, L.; Stampfer, M.J.; Rosner, B.; Bain, C.; Witschi, J.; Hennekens, C.H.; Speizer, F.E. Reproducibility and Validity of a Semiquantitative Food Frequency Questionnaire. Am. J. Epidemiol. 1985, 122, 51-65. [CrossRef] [PubMed]

23. Holmes, M.D.; Powell, I.J.; Campos, H.; Stampfer, M.J.; Giovannucci, E.L.; Willett, W.C. Validation of a food frequency questionnaire measurement of selected nutrients using biological markers in African-American men. Eur. J. Clin. Nutr. 2007, 61, 1328-1336. [CrossRef]

24. Fung, T.T.; Chiuve, S.E.; McCullough, M.L.; Rexrode, K.M.; Logroscino, G.; Hu, F.B. Adherence to a DASH-Style Diet and Risk of Coronary Heart Disease and Stroke in Women. Arch. Intern. Med. 2008, 168, 713-720. [CrossRef]

25. Arvaniti, F.; Panagiotakos, D.B. Healthy Indexes in Public Health Practice and Research: A Review. Crit. Rev. Food Sci. Nutr. 2008, 48, 317-327. [CrossRef] [PubMed]

26. Miller, P.E.; Cross, A.J.; Subar, A.F.; Krebs-Smith, S.M.; Park, Y.; Powell-Wiley, T.; Hollenbeck, A.; Reedy, J. Comparison of 4 established DASH diet indexes: Examining associations of index scores and colorectal cancer. Am. J. Clin. Nutr. 2013, 98, 794-803. [CrossRef]

27. Anderson, T.J.; Grégoire, J.; Pearson, G.; Barry, A.; Couture, P.; Dawes, M.; Francis, G.A.; Genest, J.; Grover, S.; Gupta, M.; et al. 2016 Canadian Cardiovascular Society Guidelines for the Management of Dyslipidemia for the Prevention of Cardiovascular Disease in the Adult. Can. J. Cardiol. 2016, 32, 1263-1282. [CrossRef]

28. Sievenpiper, J.L.; Chan, C.B.; Dworatzek, P.D.; Freeze, C.; Williams, S.L. Nutrition Therapy. Can. J. Diabetes 2018, 42, S64-S79. [CrossRef]

29. USDA; USDHHS. Dietary Guidelines for Americans, 2020-2025, 9th ed. Available online: https://www.dietaryguidelines.gov (accessed on 3 March 2021).

30. Government of Canada. Canada's Food Guide. Available online: https://food-guide.canada.ca/en/ (accessed on 12 April 2021).

31. Trichopoulou, A.; Costacou, T.; Bamia, C.; Trichopoulos, D. Adherence to a Mediterranean Diet and Survival in a Greek Population. N. Engl. J. Med. 2003, 348, 2599-2608. [CrossRef] [PubMed]

32. Sotos-Prieto, M.; Bhupathiraju, S.N.; Mattei, J.; Fung, T.T.; Li, Y.; Pan, A.; Willett, W.C.; Rimm, E.B.; Hu, F.B. Changes in Diet Quality Scores and Risk of Cardiovascular Disease Among US Men and Women. Circulation 2015, 132, 2212-2219. [CrossRef] [PubMed]

33. Galbete, C.; Kröger, J.; Jannasch, F.; Iqbal, K.; Schwingshackl, L.; Schwedhelm, C.; Weikert, C.; Boeing, H.; Schulze, M.B. Nordic diet, Mediterranean diet, and the risk of chronic diseases: The EPIC-Potsdam study. BMC Med. 2018, 16, 1-13. [CrossRef]

34. Satija, A.; Bhupathiraju, S.N.; Spiegelman, D.; Chiuve, S.; Manson, J.E.; Willett, W.; Rexrode, K.M.; Rimm, E.B.; Hu, F.B. Healthful and Unhealthful Plant-Based Diets and the Risk of Coronary Heart Disease in U.S. Adults. J. Am. Coll. Cardiol. 2017, 70, 411-422. [CrossRef] [PubMed] 
35. Kourlaba, G.; Panagiotakos, D. The diagnostic accuracy of a composite index increases as the number of partitions of the components increases and when specific weights are assigned to each component. J. Appl. Stat. 2010, 37, 537-554. [CrossRef]

36. D'Alessandro, A.; De Pergola, G. Mediterranean Diet and Cardiovascular Disease: A Critical Evaluation of A Priori Dietary Indexes. Nutrients 2015, 7, 7863-7888. [CrossRef]

37. Ocké, M.C. Evaluation of methodologies for assessing the overall diet: Dietary quality scores and dietary pattern analysis. Proc. Nutr. Soc. 2013, 72, 191-199. [CrossRef]

38. Mejia, S.B.; Messina, M.; Li, S.S.; Viguiliouk, E.; Chiavaroli, L.; Khan, T.A.; Srichaikul, K.; Mirrahimi, A.; Sievenpiper, J.L.; Kris-Etherton, P.; et al. A Meta-Analysis of 46 Studies Identified by the FDA Demonstrates that Soy Protein Decreases Circulating LDL and Total Cholesterol Concentrations in Adults. J. Nutr. 2019, 149, 968-981. [CrossRef]

39. Ha, V.; Sievenpiper, J.L.; de Souza, R.; Jayalath, V.H.; Mirrahimi, A.; Agarwal, A.; Chiavaroli, L.; Mejia, S.B.; Sacks, F.M.; Di Buono, M.; et al. Effect of dietary pulse intake on established therapeutic lipid targets for cardiovascular risk reduction: A systematic review and meta-analysis of randomized controlled trials. Can. Med. Assoc. J. 2014, 186, E252-E262. [CrossRef]

40. Jovanovski, E.; Yashpal, S.; Komishon, A.; Zurbau, A.; Mejia, S.B.; Ho, H.V.T.; Li, D.; Sievenpiper, J.; Duvnjak, L.; Vuksan, V. Effect of psyllium (Plantago ovata) fiber on LDL cholesterol and alternative lipid targets, non-HDL cholesterol and apolipoprotein B: A systematic review and meta-analysis of randomized controlled trials. Am. J. Clin. Nutr. 2018, 108, 922-932. [CrossRef] [PubMed]

41. Ho, H.V.T.; Sievenpiper, J.L.; Zurbau, A.; Mejia, S.B.; Jovanovski, E.; Au-Yeung, F.; Jenkins, A.L.; Vuksan, V. The effect of oat $\beta$-glucan on LDL-cholesterol, non-HDL-cholesterol and apoB for CVD risk reduction: A systematic review and meta-analysis of randomised-controlled trials. Br. J. Nutr. 2016, 116, 1369-1382. [CrossRef] [PubMed]

42. Ho, H.V.T.; Sievenpiper, J.L.; Zurbau, A.; Mejia, S.B.; Jovanovski, E.; Au-Yeung, F.; Jenkins, A.L.; Vuksan, V. Erratum: A systematic review and meta-analysis of randomized controlled trials of the effect of barley $\beta$-glucan on LDL-C, non-HDL-C and apoB for cardiovascular disease risk reductioni-iv. Eur. J. Clin. Nutr. 2016, 70, 1340. [CrossRef]

43. Sabaté, J.; Oda, K.; Ros, E. Nut Consumption and Blood Lipid Levels. Arch. Intern. Med. 2010, 170, 821-827. [CrossRef]

44. National Institute of Health and Welfare. FINELI-The National Food Composition Database. Available online: https://thl.fi/ en/web/lifestyles-and-nutrition/nutrition/fineli-the-national-food-composition-database (accessed on 17 April 2021).

45. Ras, R.T.; van der Schouw, Y.; Trautwein, E.A.; Sioen, I.; Dalmeijer, G.W.; Zock, P.; Beulens, J.W.J. Intake of phytosterols from natural sources and risk of cardiovascular disease in the European Prospective Investigation into Cancer and Nutrition-the Netherlands (EPIC-NL) population. Eur. J. Prev. Cardiol. 2015, 22, 1067-1075. [CrossRef] [PubMed]

46. USDA. U.S. Department of Agriculture. Food Data Central. Food Composition Table. Available online: https://fdc.nal.usda.gov/ (accessed on 17 April 2021).

47. Jiménez-Escrig, A.; Santos-Hidalgo, A.B.; Calixto, F.D.S. Common Sources and Estimated Intake of Plant Sterols in the Spanish Diet. J. Agric. Food Chem. 2006, 54, 3462-3471. [CrossRef]

48. Klingberg, S.; Andersson, H.; Mulligan, A.; Bhaniani, A.; Welch, A.; Bingham, S.; Khaw, K.-T.; Ellegård, L.; Andersson, S. Food sources of plant sterols in the EPIC Norfolk population. Eur. J. Clin. Nutr. 2007, 62, 695-703. [CrossRef]

49. Phillips, K.M.; Ruggio, A.D.M.; Ashraf-Khorassani, M. Phytosterol Composition of Nuts and Seeds Commonly Consumed in the United States. J. Agric. Food Chem. 2005, 53, 9436-9445. [CrossRef]

50. Normen, L.E.; Johnsson, M. A phytosterol database: Fatty foods consumed in Sweden and the Netherlands. J. Food Comp. Anal. 2007, 20, 193-201. [CrossRef]

51. Normen, L.B.; Johnsson, M. The phytosterol content of some cereal foods commonly consumed in Sweden and the Netherlands. J. Food Comp. Anal. 2002, 15, 693-704. [CrossRef]

52. Friedewald, W.T.; Levy, R.I.; Fredrickson, D.S. Estimation of the Concentration of Low-Density Lipoprotein Cholesterol in Plasma, Without Use of the Preparative Ultracentrifuge. Clin. Chem. 1972, 18, 499-502. [CrossRef]

53. Craig, C.L.; Marshall, A.L.; Sjöström, M.; Bauman, A.E.; Booth, M.L.; Ainsworth, B.E.; Pratt, M.; Ekelund, U.; Yngve, A.; Sallis, J.F.; et al. International Physical Activity Questionnaire: 12-Country Reliability and Validity. Med. Sci. Sports Exerc. 2003, 35, 1381-1395. [CrossRef] [PubMed]

54. Piedmont, R.L. Inter-item Correlations. In Encyclopedia of Quality of Life and Well-Being Research; Springer International Publishing: Berlin/Heidelberg, Germany, 2014; pp. 3303-3304.

55. Serra-Majem, L.; Andersen, L.F.; Henríque-Sánchez, P.; Doreste-Alonso, J.; Villegas, A.S.; Ortiz-Andrellucchi, A.; Negri, E.; La Vecchia, C. Evaluating the quality of dietary intake validation studies. Br. J. Nutr. 2009, 102, S3-S9. [CrossRef]

56. Carroll, R.J.; Midthune, D.; Subar, A.F.; Shumakovich, M.; Freedman, L.S.; Thompson, F.E.; Kipnis, V. Taking Advantage of the Strengths of 2 Different Dietary Assessment Instruments to Improve Intake Estimates for Nutritional Epidemiology. Am. J. Epidemiol. 2012, 175, 340-347. [CrossRef]

57. Kourlaba, G.; Panagiotakos, D. The Number of Index Components Affects the Diagnostic Accuracy of a Diet Quality Index: The Role of Intracorrelation and Intercorrelation Structure of the Components. Ann. Epidemiol. 2009, 19, 692-700. [CrossRef] [PubMed]

58. Altman, D.G. The cost of dichotomising continuous variables. Br. Med. J. 2006, 332, 1080. [CrossRef] [PubMed]

59. Hu, F.B.; Rimm, E.; Smith-Warner, S.A.; Feskanich, D.; Stampfer, M.J.; Ascherio, A.; Sampson, L.; Willett, W.C. Reproducibility and validity of dietary patterns assessed with a food-frequency questionnaire. Am. J. Clin. Nutr. 1999, 69, 243-249. [CrossRef]

60. Weinstein, S.J.; Vogt, T.M.; Gerrior, S.A. Healthy eating index scores are associated with blood nutrient concentrations in the third National Health and Nutrition Examination Survey. J. Am. Diet. Assoc. 2004, 104, 576-584. [CrossRef] 
61. Hann, C.S.; Rock, C.L.; King, I.; Drewnowski, A. Validation of the Healthy Eating Index with use of plasma biomarkers in a clinical sample of women. Am. J. Clin. Nutr. 2001, 74, 479-486. [CrossRef]

62. Newby, P.K.; Hu, F.B.; Rimm, E.B.; Smith-Warner, S.A.; Feskanich, D.; Sampson, L.; Willett, W.C. Reproducibility and validity of the Diet Quality Index Revised as assessed by use of a food-frequency questionnaire. Am. J. Clin. Nutr. 2003, 78, 941-949. [CrossRef] [PubMed]

63. Satija, A. Plant-Based Diets and Risk of Type 2 Diabetes and Coronary Heart Disease; Harvard T.H. Chan School of Public Health: Boston, MA, USA, 2016.

64. Beaton, G.H.; Milner, J.; Corey, P.; McGuire, V.; Cousins, M.; Stewart, E.; De Ramos, M.; Hewitt, D.; Grambsch, P.V.; Kassim, N.; et al. Sources of variance in 24-hour dietary recall data: Implications for nutrition study design and interpretation. Am. J. Clin. Nutr. 1979, 32, 2546-2559. [CrossRef]

65. Khani, B.R.; Ye, W.; Terry, P.; Wolk, A. Reproducibility and Validity of Major Dietary Patterns among Swedish Women Assessed with a Food-Frequency Questionnaire. J. Nutr. 2004, 134, 1541-1545. [CrossRef] [PubMed]

66. Benítez-Arciniega, A.A.; Mendez, M.A.; Baena-Diez, J.M.; Martori, M.-A.R.; Soler, C.; Marrugat, J.; Covas, M.-I.; Sanz, H.; Llopis, A.; Schroder, H. Concurrent and construct validity of Mediterranean diet scores as assessed by an FFQ. Public Health Nutr. 2011, 14, 2015-2021. [CrossRef] [PubMed]

67. Ambrosini, G.L.; Van Roosbroeck, S.A.H.; Mackerras, D.; Fritschi, L.; De Klerk, N.H.; Musk, A.W. The reliability of ten-year dietary recall: Implications for cancer research. J. Nutr. 2003, 133, 2663-2668. [CrossRef]

68. Feskanich, D.; Rimm, E.B.; Giovannucci, E.L.; Colditz, G.; Stampfer, M.J.; Litin, L.B.; Willett, W.C. Reproducibility and validity of food intake measurements from a semiquantitative food frequency questionnaire. J. Am. Diet. Assoc. 1993, 93, 790-796. [CrossRef]

69. Willett, W.L.E. Reproducibility and valdiity of food frequency questionnaires. In Nutritional Epidemiology, 3th ed.; Oxford University Press: New York, NY, USA, 2012.

70. Auclair, O.; Burgos, S.A. Protein consumption in Canadian habitual diets: Usual intake, inadequacy, and the contribution of animal- and plant-based foods to nutrient intakes. Appl. Physiol. Nutr. Metab. 2021, 46, 501-510. [CrossRef] 